\title{
Gnaisse Turvo: registro de magmatismo paleoproterozoico no Terreno Paraguá - sudoeste do Cráton Amazônico, Vila Bela da Santíssima Trindade, Mato Grosso
}

\author{
Turvo Gneiss: paleoproterozoic magmatism record in Paraguá \\ Terrane - southwest of Amazonian Craton, Vila Bela da Santíssima \\ Trindade, Mato Grosso
}

\author{
Fernando Lisboa Pinto de Figueiredo ${ }^{1,4 *}$, Amarildo Salina Ruiz ${ }^{1,3,4,6}$, Maria Zélia \\ Aguiar de Sousa ${ }^{1,2,4,6}$, Moacir José Buenano Macambira ${ }^{4,5,6}$
}

RESUMO: O Gnaisse Turvo, objeto deste trabalho, corresponde a um ortognaisse polideformado exposto na regiáo de Vila Bela da Santíssima Trindade, sudoeste do estado de Mato Grosso. Do ponto de vista geotectônico, está inserido no Cráton Amazônico e representa o embasamento paleoproterozoico do Terreno Paraguá, um dos blocos crustais que formam a Província Rondoniana-San Ignácio $(1,55-1,3 \mathrm{Ga})$. Duas fácies foram identificadas a partir do estudo petrográfico: granada-anfibólio-biotita gnaisse formada por granodioritos e anfibólio-biotita gnaisse, mais abundante, de composição granodiorítica a sienogranítica. A paragênese identificada caracteriza o metamorfismo responsável por esses gnaisses como da fácies anfibolito. A análise estrutural caracteriza duas fases de deformação em nível crustal dúctil. A mais antiga $\left(\mathrm{F}_{1}\right)$ é responsável pelo desenvolvimento do bandamento gnáissico, enquanto as estruturas da fase $\left(\mathrm{F}_{2}\right)$, orientadas segundo a direção N30-60W, indicam esforços compressivos com transporte tectônico de SW para NE. A idade mínima de cristalização do Gnaisse Turvo, definida pelo método $\mathrm{Pb}-\mathrm{Pb}$ em evaporação de zircáo, corresponde a $1651 \pm$ $4 \mathrm{Ma}$, sendo interpretada como idade de colocaçáo do protólito ígneo. Os dados litogeoquímicos indicam que significativo magmatismo calcioalcalino de alto-K, metaluminoso a peraluminoso, associado à evolução de arcos magmáticos em ambiente de subducção (Orogenia Lomas Manechis - 1,7 a 1,6 Ga), dominava o período estateriano no Terreno Paraguá. A unidade ortognáissica estudada foi posteriormente retrabalhada metamórfica e tectonicamente, durante a Orogenia San Ignácio $\left(1,4\right.$ a 1,3 Ga), que provavelmente corresponde à fase de deformação $F_{2}$.

PALAVRAS-CHAVE: Gnaisse Turvo; Cráton Amazônico; Terreno Paraguá; Geocronologia $(\mathrm{Pb}-\mathrm{Pb})$.
ABSTRACT: The Turvo Gneiss, object of this work, corresponds to a polideformed orthogneiss exposed in the region of Vila Bela da Santíssima Trindade, southwestern of state of Mato Grosso. From the tectonic point of view, is inserted into the Amazon Craton and represents the Paleoproterozoic basement of the Paragua Terrain, one of the crustal blocks that form the Province Rondonian-San Ignacio (1.55-1.3 Ga). Two facies were identified from petrographic study: garnet-amphibole-biotite gneiss composed of granodiorite and biotite-amphibole gneiss, more abundant, with granodioritic to syenogranitic composition. The metamorphic paragenesis identified characterizes as responsible for these gneisses of amphibolite facies. The structural analysis features two stages of deformation in ductil crustal level. The oldest $\left(F_{1}\right)$ is responsible for developing the gneissic banding, while the structures of phase $\left(F_{2}\right)$, the second oriented N30-60W indicate compressive stress with tectonic transport from $S W$ to $N E$. The minimum age of crystallization of the Turvo Gneiss defined by Pb-Pb method on zircon evaporation corresponds to $1651 \pm 4 \mathrm{Ma}$ and is interpreted as emplacement age of igneous protolith. The data indicate that significant lithogeochemical calcium-alkaline magmatism of high $K$, metaluminous to peraluminous, associated with magmatic evolution in a subduction environment (Lomas Manechis Orogeny - 1.7 to $1.6 \mathrm{Ga}$ ), dominated the period Estaterian in the Paragua Terrain. The orthogneissic unit studied was later reworked, metamorphic and tectonic $\left(F_{2}\right)$, during the San Ignacio Orogeny (1.4 to $1.3 \mathrm{Ga}$ ).

KEYWORDS: Turvo Gneiss; Amazon Craton; Paraguá Terrane; Geochronology $(\mathrm{Pb}-\mathrm{Pb})$.

\footnotetext{
${ }^{1}$ Programa de Pós-graduação em Geociências, Instituto de Ciências Exatas e da Terra - ICET, Universidade Federal de Mato Grosso - UFMT, Cuiabá (MT), Brasil. E-mail:ferlifig@gmail.com

${ }^{2}$ Departamento de Recursos Minerais, ICET, UFMT. E-mail:prof.mzaguiar@gmail.com

32Departamento de Geologia Geral, ICET, UFMT. E-mail: asruiz@gmail.com

${ }^{4}$ Grupo de Pesquisa em Evolução Crustal e Tectônica - Guaporé (RS), Brasil.

${ }^{5}$ Laboratório de Geocronologia Pará-Iso, Universidade Federal do Pará - UFPA, Belém (PA), Brasil. E-mail: moamac@ufpa.br

${ }^{6}$ Instituto Nacional de Ciência e Tecnologia em Geociências da Amazônia, Universidade Federal do Pará - UFPA, Belém (PA), Brasil.

Manuscrito ID 26555. Recebido em: 13/04/2012. Aprovado em: 12/04/2013
} 


\section{INTRODUÇÃO}

O conhecimento geológico do extremo ocidente do estado de Mato Grosso na região fronteiriça com a Bolívia vem sendo, ao longo dos últimos anos, ampliado, principalmente em função da incorporaçáo de novos dados geológicos, estruturais, geoquímicos e geocronológicos (Ruiz et al. 2007, Figueiredo et al. 2009, Jesus et al. 2010, Nalon et al. 2013). As informaçôes atuais confirmam o prolongamento do Terreno Paraguá em território brasileiro e indicam que o mesmo é constituído por unidades gnáissicas e granulíticas paleoproterozoicas afetadas pelas orogenias San Ignácio (1,4-1,3 Ga) e Sunsás (1,0 - 0,9 Ga). Com o propósito de contribuir para a compreensão da evoluçáo geológica do Terreno Paraguá no Brasil, será apresentado e discutido um acervo de dados geológicos, petrográficos, geoquímicos, geocronológicos ( $\mathrm{Pb}-\mathrm{Pb}$ por evaporaçáo de $\mathrm{Pb}$ em monocristais de zircáo) e estruturais do Gnaisse Turvo, que constitui importante registro magmático paleoproterozoico na regiáo de Vila Bela da Santíssima Trindade, Mato Grosso.

\section{CONTEXTO GEOLÓGICO REGIONAL}

\section{Cráton Amazônico}

O extremo ocidente do estado de Mato Grosso está inserido no contexto geológico da Província RondonianaSan Ignacio, que representa um fragmento crustal descrito como parte de um conjunto de cinturóes móveis acrescidos a um núcleo cratônico, contextualizando o Cráton Amazônico (Cordani et al. 1979). Estudos posteriores (Tassinari 1996, Tassinari \& Macambira 1999, 2004), principalmente de cunho geocronológico, definiram o Cráton Amazônico como o resultado da acresção continental a partir de um proto-cráton Arqueano (Província Amazônia Central - 2,5 Ga), composto por microcontinentes amalgamados em orogenias colisionais associado a outras cinco províncias geocronológicas denominadas de Maroni-Itacaiúnas $(2,2-1,95 \mathrm{Ga})$, Ventuari-Tapajós (1,95 - 1,8 Ga), Rio Negro-Juruena $(1,8$ - 1,55 Ga), Rondoniana-San Ignacio (1,55 $1,3 \mathrm{Ga})$ e Sunsás (1,3 - 1,0 Ga). As províncias VentuariTapajós e Rio Negro-Juruena são compostas por material derivado do manto evoluído em uma sucessão de arcos magmáticos, enquanto as outras províncias apresentam retrabalhamento associado a processos colisionais (Tassinari et al. 2000, Tassinari \& Macambira 2004). Santos et al. (2000) propuseram uma configuração para o Cráton Amazônico abrangendo as províncias geocronológicas Carajás-Imataca $(3,10-2,53 \mathrm{Ga})$,
Transamazônica (2,25 - 2,00 Ga), Tapajós-Parima (2,10 - 1,87 Ga), Central Amazônica (1,88 - 1,70 Ga), Rio Negro (1,86 - 1,52 Ga), Rondônia-Juruena (1,76 1,47 Ga), K’Mudku (1,33 - 1,10 Ga) e Sunsás (1,33 0,99 Ga). Ruiz (2005) e Cordani et al. (2010) acrescentam o cráton ou bloco Rio Apa ao Cráton Amazônico, estendendo sua área de ocorrência até o extremo sul da Faixa Móvel Paraguai (Fig. 1).

A Província Rondoniana-San Ignacio, onde se insere a unidade estudada, é limitada ao norte e leste pela Província Rio Negro-Juruena, a sul pela Província Sunsás e a oeste por sequências sedimentares fanerozoicas e é caracterizada por um fragmento formado por amalgamaçáo de arcos magmáticos em colisão continental ao longo do limite com a Província Rio Negro-Juruena (Cordani e Teixeira 2007). Segundo Bettencourt et al. (2010), a cratonização da Província Rondoniana-San Ignacio foi seguida por reativação tectônica, deformação, metamorfismo e magmatismo relacionados a eventos orogênicos mais jovens. Estes efeitos são observados em feições como zonas de cisalhamentos, riftes, bacias sedimentares e intrusôes sin a pós-tectônicas e anorogênicas. Estes autores subdividiram essa província nos seguintes fragmentos crustais: Terreno Paraguá (1,82 - 1,32 Ga), Terreno Jauru (1,78 - 1,42 Ga), Terreno Rio Alegre $(1,51-1,38 \mathrm{Ga})$ e o Cinturão Alto Guaporé (Fig. 2).

\section{Terreno Paraguá}

O Terreno Paraguá está inserido no contexto da Província Rondoniana-San Ignácio sendo primeiramente estudado por Litherland et al. (1986), os quais o descreveram, no extremo oriente boliviano, como "Cráton Paraguâ". Estes definiram um embasamento composto pelos complexos gnáissico-granulíticos Chiquitania e Lomas Manechis e por rochas supracrustais metassedimentares do Supergrupo Xistos San Ignácio, intrudidos pela granitogênese de afinidade calcioalcalina do Complexo Granitoide Pensamiento. Boger et al. (2005) reinterpretaram, a partir de novos dados estruturais e isotópicos, as unidades do oriente boliviano. Posicionaram a deposição dos protólitos sedimentares do Complexo Gnáissico Chiquitania e Grupo San Ignacio simultaneamente à colocação da Suíte Granulítica Lomas Manechis em 1690 Ma e reforçaram a existência de deformação e metamorfismo destas unidades durante a Orogenia San Ignacio $(1340-1320 \mathrm{Ma})$. Adicionalmente, os autores sugeriram que o Terreno Paraguá foi aglutinado ao Cráton Amazônico durante a Orogenia Sunsás. Santos et al. $(2000,2008)$ estabeleceram a evolução cronológica da Província Rondônia-Juruena e do Orógeno Sunsás entre os períodos $1,84-1,54$ Ga e 1,46 - 1,11 Ga, 


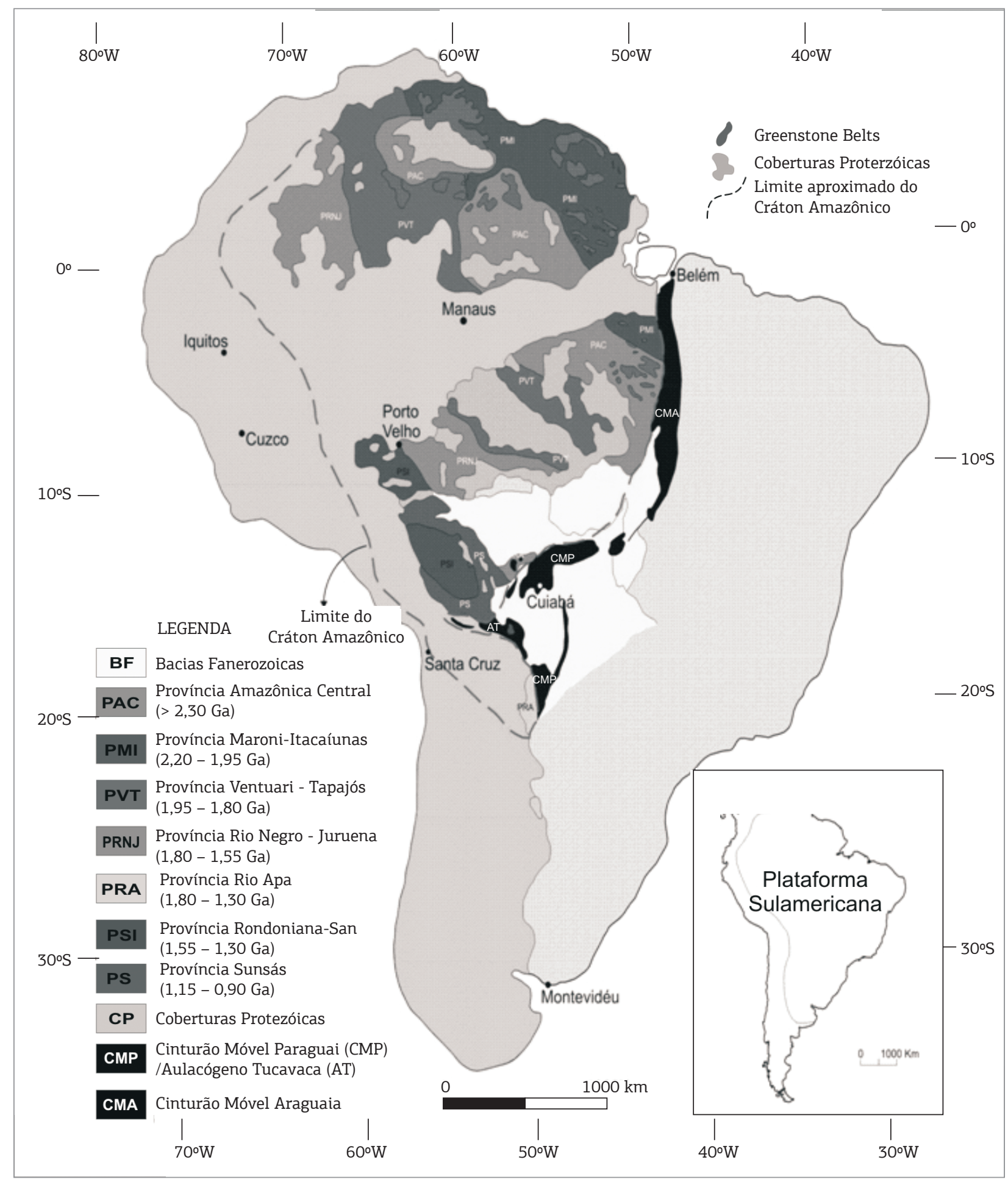

Figura 1. Configuração das províncias geocronológicas do Cráton Amazônico incluindo a província Rio Apa (extraído de Ruiz, 2005).

respectivamente, e definiram uma evolução in situ para este orógeno contrariando, assim, a ideia de microcontinente alóctone para o Cráton Paraguá. A área de estudo (Fig. 2) está inserida na porção do Terreno Paraguá que não foi afetada pela Orogenia Sunsás. Os mapeamentos geológicos executados e as informaçôes geocronológicas disponíveis (Ruiz et al. 2007, Ruiz 2009, Figueiredo et al. 2009, Figueiredo 2010, Jesus et al. 2010, Nalon 2010) para a região de Vila Bela da Santíssima Trindade (Fig. 3), sugerem o seguinte empilhamento estratigráfico em 


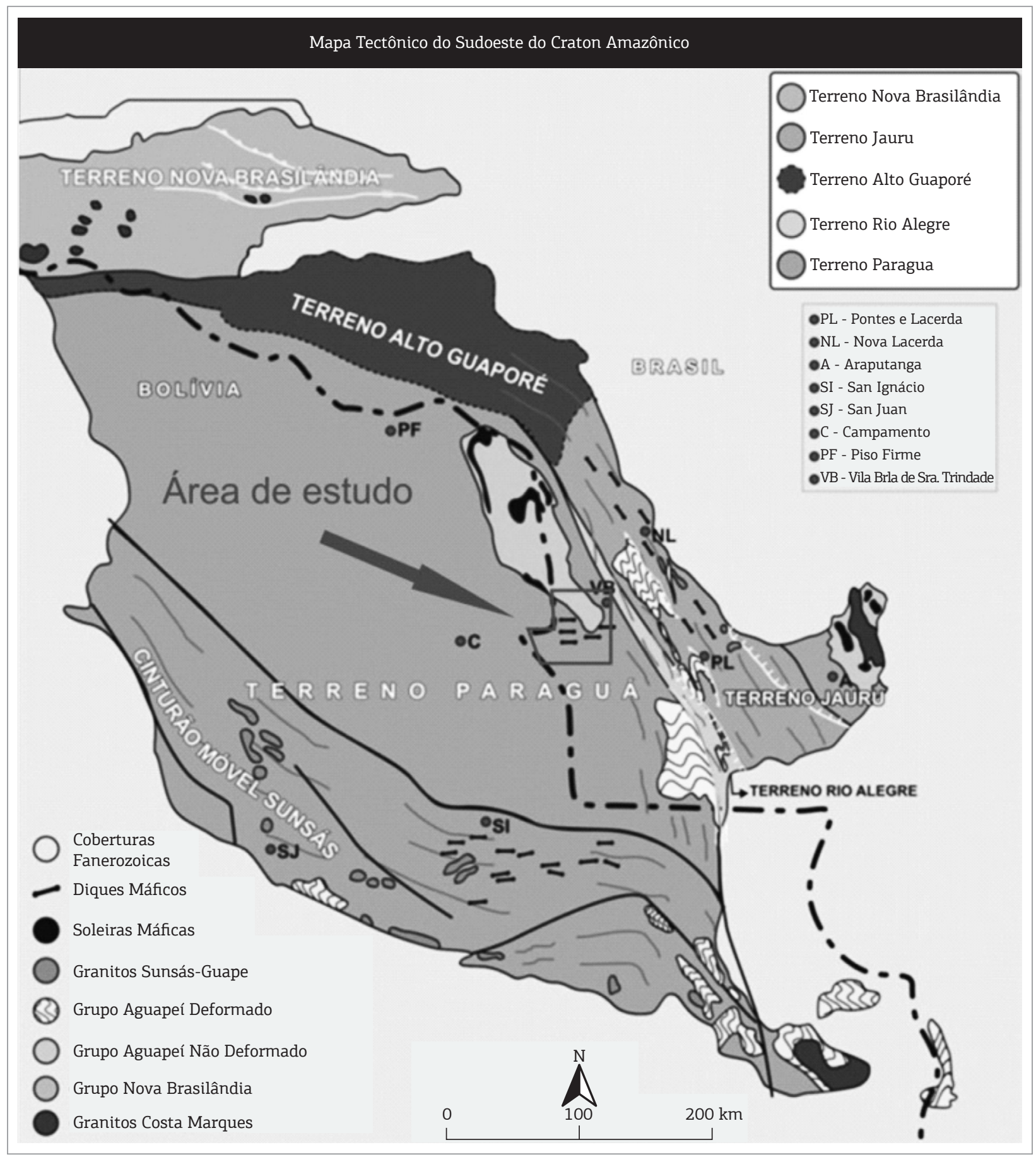

Figura 2. Configuração tectônica do sudoeste do Cráton Amazônico no extremo ocidente do estado de Mato Grosso (modificado de Ruiz 2009).

ordem cronológica decrescente: Complexo Metamórfico Ricardo Franco, Gnaisse Turvo, Granito Fronteira, Ortognaisse Shangri-lá, Granito Cascata, Complexo Granitoide Pensamiento composto pelos granitos Guaporeí e Passagem, Suíte Intrusiva Guará, Granito Vila Bela, Grupo Aguapeí e Suíte Intrusiva Huanchaca (Tab. 1; Fig. 3).

\section{GEOLOGIA E PETROGRAFIA}

O Gnaisse Turvo corresponde a um corpo orientado segundo a direção NNW com cerca de $200 \mathrm{~km}^{2}$ de extensão. Ocorre em uma área muito aplainada, sendo em grande parte oculto por coberturas lateríticas e sedimentos inconsolidados coluvionares e aluvionares. Boas 
Tabela 1. Coluna estratigráfica proposta para as unidades mapeadas na área de estudo e idades de algumas dessas unidades

\begin{tabular}{|c|c|c|c|c|}
\hline $\begin{array}{l}\text { Suíte Intrusiva Huanchaca } \\
{ }^{*} 888 \pm 20(\mathrm{~K}-\mathrm{Ar}) \\
{ }^{*} 845 \pm 19(\mathrm{~K}-\mathrm{Ar})\end{array}$ & \multicolumn{4}{|c|}{ sills e diques de diabásio } \\
\hline $\begin{array}{l}\text { Grupo Aguapeí } \\
* * 1.149 \pm 7(\mathrm{U}-\mathrm{Pb})\end{array}$ & \multicolumn{4}{|c|}{ ruditos e psamitos basais da Formação Fortuna } \\
\hline Granito Vila Bela & \multicolumn{4}{|c|}{ biotita-muscovita-granada granito } \\
\hline Suíte Intrusiva Guará & \multicolumn{4}{|c|}{$\begin{array}{l}\text { (complexo máfico-ultramáfico) } \\
\text { gabro, hornblenda gabro, diabásio e piroxênio hornblendito }\end{array}$} \\
\hline \multirow[t]{2}{*}{ Complexo Granitoide Pensamiento } & \multicolumn{2}{|c|}{$\begin{array}{l}\text { Granito Passagem } \\
* * * 1.284 \pm 20(\mathrm{U}-\mathrm{Pb})\end{array}$} & \multicolumn{2}{|c|}{$\begin{array}{l}\text { stocks e plugs de granito fino equigranular } \\
\text { pós-orogênico }\end{array}$} \\
\hline & \multicolumn{2}{|c|}{$\begin{array}{c}\text { Granito Guaporeí } \\
* * * * 1.314 \pm 2(\mathrm{~Pb}-\mathrm{Pb}) \\
\mathrm{T}_{\mathrm{DM}} 1,76 \mathrm{Ga} \\
\varepsilon_{\mathrm{Nd}(t)}=(-14)(\mathrm{Sm}-\mathrm{Nd})\end{array}$} & \multicolumn{2}{|c|}{$\begin{array}{c}\text { batólito sin-orogênico de composição } \\
\text { variada }\end{array}$} \\
\hline Granito Cascata & \multicolumn{4}{|c|}{ granodiorito foliado rico em minerais máficos e opacos } \\
\hline Ortognaisse Shangri-lá & $\begin{array}{l}\text { granada-biotita } \\
\text { gnaisse } \\
\text { (tonalítico) }\end{array}$ & \multicolumn{2}{|c|}{$\begin{array}{l}\text { anfibólio-biotita gnaisse } \\
\text { (granodiorítico) }\end{array}$} & $\begin{array}{l}\text { anfibólio-biotita } \\
\text { gnaisse } \\
\text { (monzogranítico) }\end{array}$ \\
\hline Granito Fronteira & \multicolumn{4}{|c|}{$\begin{array}{l}\text { monzogranito foliado com porfiroclastos de feldspato potássico e lineação de máficos e } \\
\text { opacos }\end{array}$} \\
\hline $\begin{array}{l}\text { Ortognaisse Turvo } \\
* * * * * 1.651 \pm 4(\mathrm{~Pb}-\mathrm{Pb})\end{array}$ & \multicolumn{2}{|c|}{$\begin{array}{l}\text { granada-anfibólio-biotita gnaisse } \\
\text { (granodiorítico) }\end{array}$} & \multicolumn{2}{|c|}{$\begin{array}{c}\text { anfibólio-biotita gnaisse (granodiorítico a } \\
\text { sienogranítico) }\end{array}$} \\
\hline Complexo Metamórfico Ricardo Franco & \multicolumn{4}{|c|}{ hornblenda anfibolito, sillimanita-granada gnaisse, granada quartzito } \\
\hline
\end{tabular}

Pb-Pb: idade por evaporação de Pb em monocristais de zircão; *Litherland et al. 1986, ${ }^{* *}$ Santos et al. 2008, ${ }^{* * *}$ Jesus et al. (2010), ${ }^{* * * *}$ Nalon 2010, ${ }^{* * * * *}$ este trabalho.

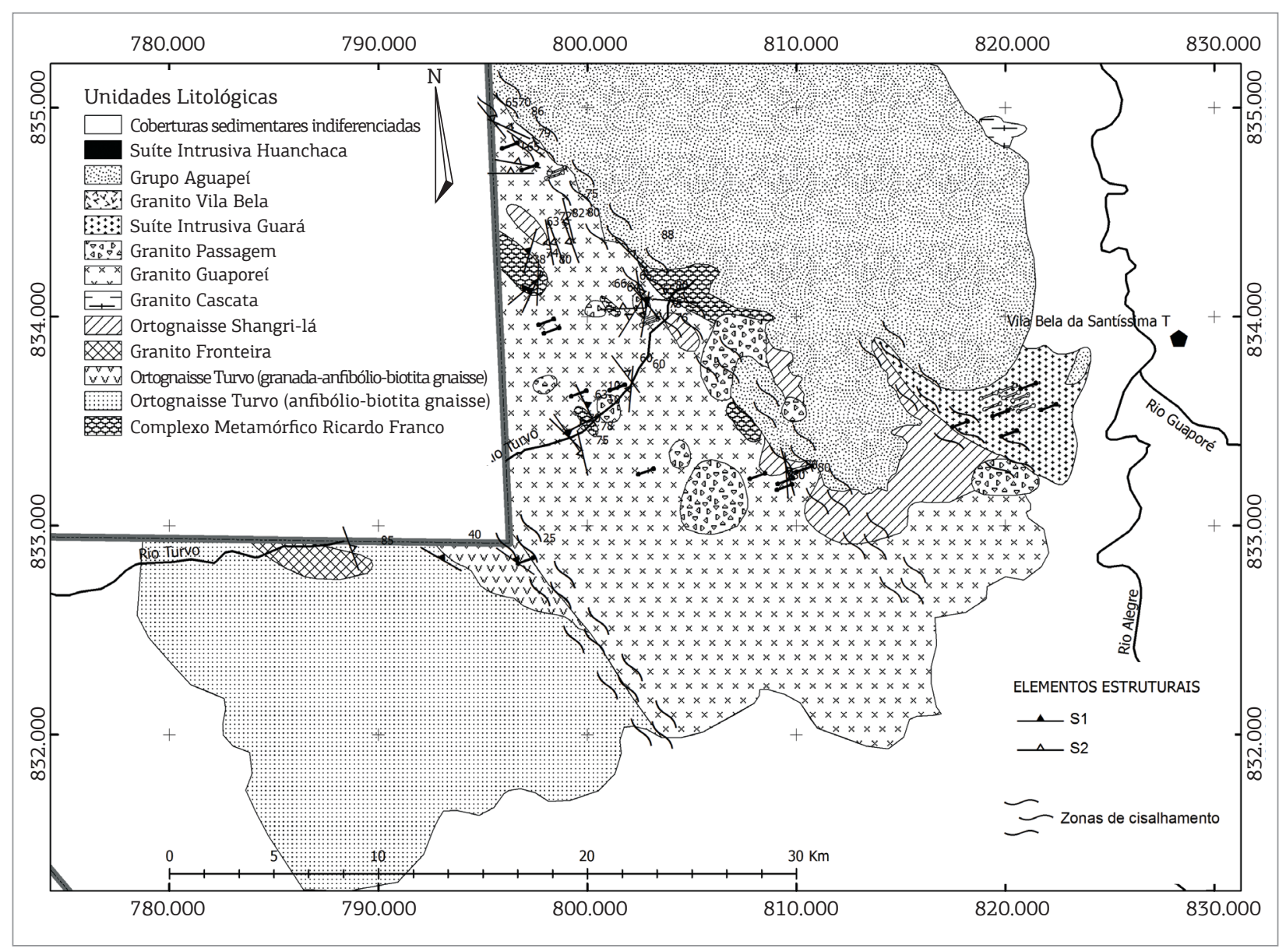

Figura 3. Mapa geológico do Terreno Paraguá na região de Vila Bela da Santíssima Trindade - MT. 
exposiçóes, sob a forma de blocos, matacóes e lajedos, são encontradas principalmente nas imediaçóes do Granito Guaporeí. O Gnaisse Turvo é recoberto, a sul e oeste, por sedimentos coluvionares, a leste faz contato tectônico com o Granito Guaporeí e a nordeste é intrudido pelo Granito Fronteira. Duas fácies petrográficas foram individualizadas com base na constituição mineralógica: a mais abundante, de composição granodiorítica a sienogranítica, corresponde à fácies anfibólio-biotita gnaisse e a outra, que se restringe à área próxima ao contato com o Granito Guaporeí, compreende a fácies granada-anfibólio-biotita gnaisse de composição essencialmente granodiorítica. Não há relação de contato visível entre as duas fácies petrográficas cartografadas. A fácies anfibólio-biotita gnaisse é representada por rochas anisotrópicas, leucocráticas, de cor cinza esbranquiçado, granulação média a grossa, inequigranulares a raramente porfiroclásticas, apresentando natureza polideformada com transposiçóes de foliaçóes e estruturas de redobramentos, bem como xenólitos máficos. Exibe bandamento milimétrico a centimétrico, descontínuo, com leitos félsicos de cor cinza esbranquiçado a cinza rosado formados por agregados de quartzo, feldspato alcalino e plagioclásio permeados por biotita e anfibólio; e leitos máficos de cor cinza escuro, onde predominam agregados orientados de biotita e anfibólio (Fig. 4A). A fácies granada-anfibólio-biotita gnaisse consiste de litotipos orientados, meso a leucocráticos de cor cinza escuro, granulação média a grossa, bandados, sendo comum a segregação de leitos quartzo-feldspáticos ricos em granada, apresentando transposição do bandamento gnáissico (Fig. 4B). A presença de xenólitos de metagabros e anfibolitos e de microestruturas magmáticas reliquiares, em ambas as fácies, caracteriza a natureza ortoderivada da unidade (Fig. 4C). Encontram-se ainda, principalmente na fácies granada-anfibólio-biotita gnaisse, bolsões estirados, dobrados e transpostos formados essencialmente por
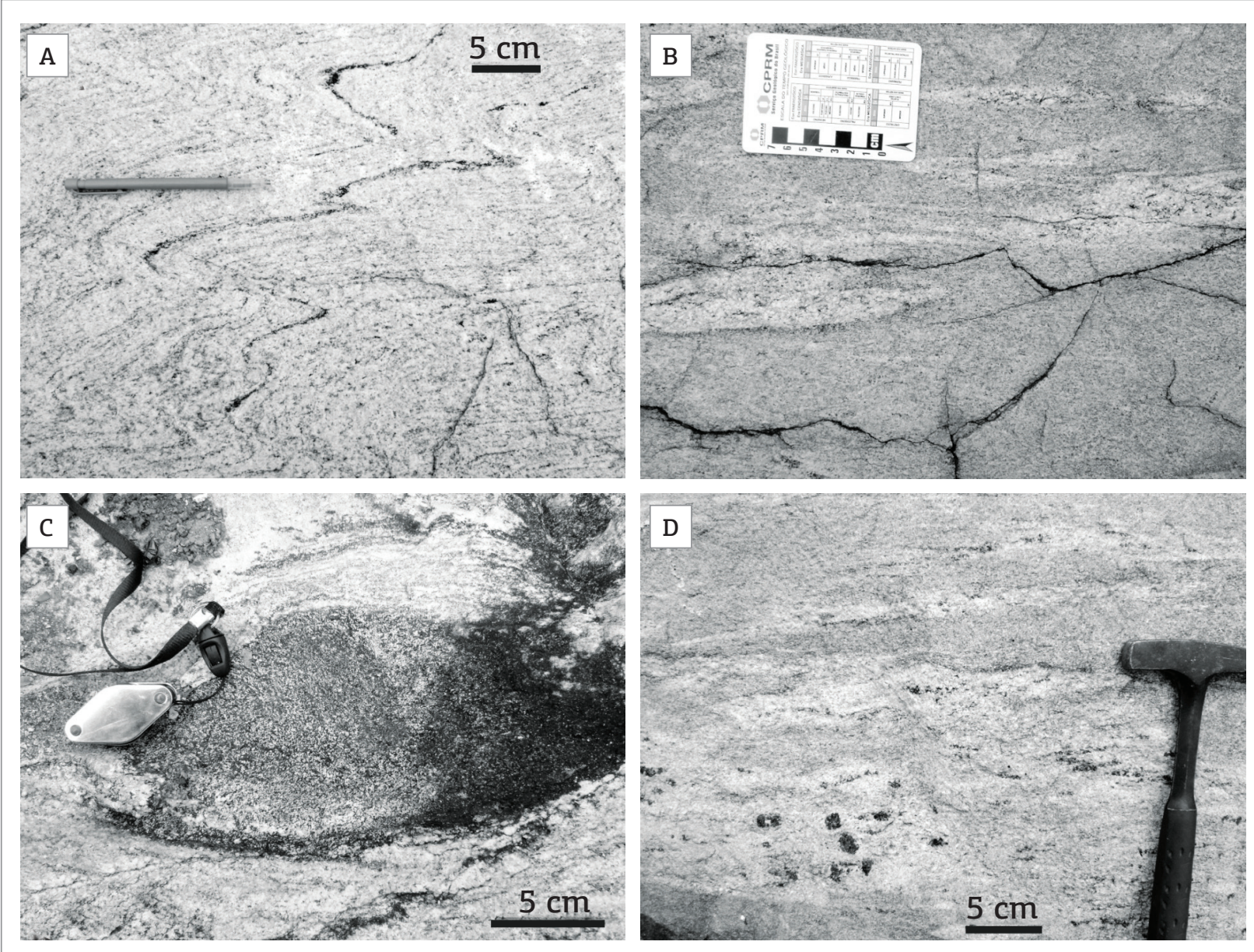

Figura 4. Afloramentos do Gnaisse Turvo. (A e B) Feições típicas das fácies anfibólio-biotita gnaisse e granadaanfibólio-biotita gnaisse, respectivamente; (C) xenólito de anfibolito com borda de reação em rochas da fácies anfibólio-biotita gnaisse; (D) Bolsões hololeucocráticos com porfiroblastos/poiquiloblastos de granada da fácies granada-anfibólio-biotita gnaisse. 
quartzo, feldspatos e raros cristais de biotita e anfibólio e grande quantidade de cristais neoformados de granada de cor marrom avermelhado claro constituindo poiquiloblastos/porfiroblastos de dimensóes médias entre 0,5 e 3 mm (Fig. 4D).

Opticamente, as rochas do Gnaisse Turvo apresentam texturas granoblástica, lepidoblástica e nematoblástica formadas pelo alinhamento de cristais de biotita e anfibólio em clara associação com o arranjo, por vezes, em mosaico dos grãos de quartzo e feldspatos. Ambas as fácies são constituídas, essencialmente, por quartzo, feldspatos alcalinos, plagioclásio, biotita e anfibólio, tendo titanita, zircão, rutilo, apatita, allanita e opacos como fases acessórias e clorita, sericita, muscovita, argilominerais, epídoto e opacos como minerais de alteração. $\mathrm{O}$ granada-anfibólio-biotita gnaisse apresenta como máficos a biotita, anfibólio e cristais neoformados de granada. Os feldspatos alcalinos estáo representados principalmente pela microclina com geminação em grade e, mais raramente, pelo ortoclásio náo geminado ou com macla Carlsbad, mostrando por vezes, alteraçáo para sericita, muscovita e argilominerais; ocorrem em grãos de tamanho médio ou localmente como porfiroclastos anédricos, às vezes poiquilíticos, com inclusóes de quartzo, plagioclásio, biotita e titanita, localmente envolvidos por gráos menores neoformados de quartzo, microclina e plagioclásio com textura mirmequítica (Fig. 5A). Texturas pertíticas são frequentes, onde a fase hóspede ocorre em chamas, filmes e em grãos que se apresentam com núcleo mais alterado e borda mais límpida, sugerindo zonação normal, respectivamente mais cálcica e sódica (Fig. 5B); intercrescimentos gráfico e granofírico são observados, principalmente, na fácies anfibólio-biotita gnaisse. $\mathrm{O}$ plagioclásio apresenta-se intercrescido com a microclina ou constitui cristais isolados, tendo sido classificado como oligoclásio; seus raros porfiroclastos ocorrem, geralmente, com formas tabulares subédricas exibindo geminação albita ou periclina e lamelas fraturadas; mostra intercrescimento mirmequítico, até mesmo quando constitui fase hóspede das pertitas e, invariavelmente, apresenta-se saussuritizado, sericitizado ou argilizado. $\mathrm{O}$ quartzo ocorre em grãos anédricos recristalizados em suas bordas e com contatos lobados e localmente poligonizados ou como intercrescimento de aspecto vermicular e cuneiforme, no plagioclásio e feldspatos alcalinos constituindo, respectivamente, texturas mirmequítica e gráfica; exibe, comumente, efeitos de deformação e recristalização evidenciados através de extinção ondulante, lamelas de deformação e crescimento de subgrãos localmente apresentando texturas em tabuleiro de xadrez (Fig. 5C). A biotita é o componente máfico primário dominante das duas fácies e ocorre em lamelas isoladas ou como palhetas e plaquetas anédricas a subédricas, com pleocroísmo castanho claro a marrom-escuro, podendo constituir, por vezes, agregados orientados que configuram os níveis finos lepidoblásticos. Inclui, frequentemente, titanita, apatita e cristais de zircão, que nela desenvolve halos pleocroicos e, por vezes, encontra-se oxidada com exsolução de minerais opacos ou também, parcialmente, transformada em muscovita ou clorita. O anfibólio, identificado como hornblenda, ocorre em prismas subédricos a anédricos, de pleocroísmo verde-escuro a marrom, estando intimamente associado à biotita, ao epídoto e à titanita (Fig. 5D). Na fácies granada-anfibóliobiotita gnaisse, a hornblenda constitui textura coronítica da granada indicando um processo de retrometamorfismo (Fig. 5E). A granada apresenta-se em agregados granulares constituindo níveis poiquiloblásticos/porfiroblásticos, subédricos a anédricos, arredondados, muito fraturados de cor marrom avermelhado (Fig. 5F), associados ao arranjo granoblástico ou às estruturas orientadas, sejam elas as texturas lepidoblásticas ou nematoblásticas (Figs. 5G e H).

\section{DEFORMAÇÃO}

A natureza polideformada das unidades gnáissicas e granulíticas do Terreno Paraguá é apontada em levantamentos estruturais realizados em território boliviano (Litherland et al. 1986, Boger et al. 2005) e brasileiro (Matos e Ruiz 1991, Ruiz 2005, Jesus et al. 2010). A análise estrutural em escala de semidetalhe demonstrou que pelo menos duas fases de deformação dúctil afetaram o Gnaisse Turvo. As fases de deformação serão designadas como $\mathrm{F}_{1}$ e $\mathrm{F}_{2}$, e os elementos estruturais, dobras, foliaçóes e lineaçóes, serão referidos como D, S e L, seguidos do número da fase de deformaçáo em que foi gerado, por exemplo, a foliação $S_{1}$, refere-se à foliação gerada na primeira fase de deformação $\left(\mathrm{F}_{1}\right)$.

\section{Primeira fase de deformação}

$\mathrm{O}$ registro deformacional mais antigo, gerado durante a Fase $F_{1}$, é definido pelo bandamento gnáissico $\left(S_{1}\right)$, tanto no anfibólio-biotita gnaisse, quanto no granada-anfibólio-biotita gnaisse. No anfibólio-biotita gnaisse, o bandamento é caracterizado pela segregação das bandas bem definidas pela orientação preferencial de minerais máficos, representados por biotita e anfibólio alinhados de acordo com a direção do bandamento e dos minerais félsicos representados por quartzo e feldspatos arranjados em uma textura granoblástica (Figs. 6A, C e D). O granada-anfibólio-biotita gnaisse apresenta as mesmas características, porém, nessa fácies é notada a presença de cristais neoformados de granada associados às texturas granoblástica, lepidoblástica e nematoblástica (Figs. 6B, E e F). 

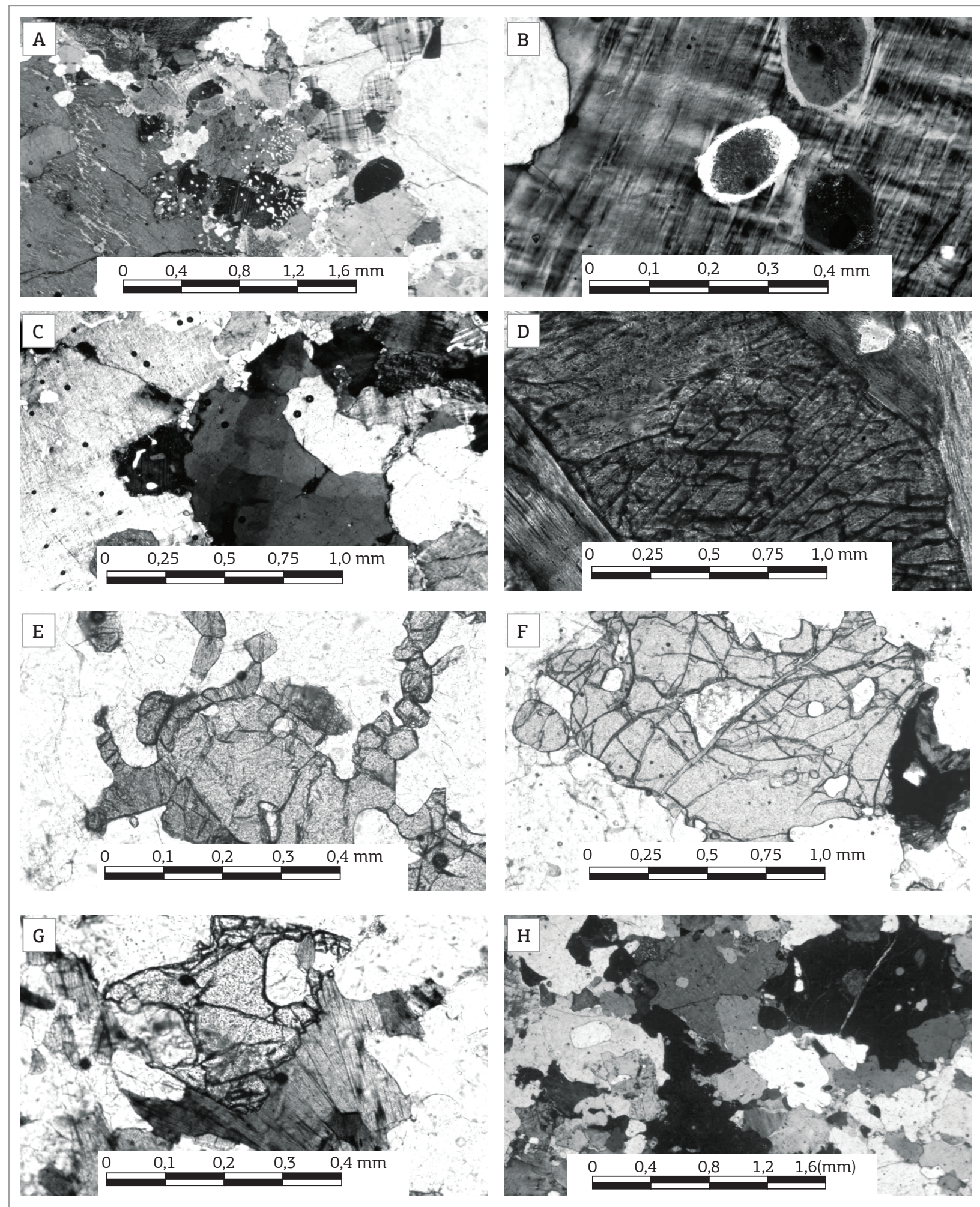

Figura 5. Fotomicrografias de rochas do Gnaisse Turvo ilustrando. (A) Porfiroclasto de microclina pertítica associado a grãos neoformados de microclina, quartzo e plagioclásio mirmequítico; (B) detalhe de microclina apresentando textura pertítica em grãos que exibem zonação normal; (C) pertita, mirmequitas e quartzo deformado com extinção ondulante e textura em tabuleiro de xadrez; (D) detalhe de banda máfica com seção basal de hornblenda associada a palhetas de biotita; (E) Agregado de granada e textura coronítica de hornblenda; (F) feição típica de um poiquiloblasto de granada; (G) parte de nível máfico formado por palhetas de biotita e grão poiquilítico de granada; $(\mathrm{H})$ textura granoblástica constituída por quartzo, microclina, plagioclásio e grão poiquilítico neoformado de granada. Polarizadores paralelos em D, E, F e G e cruzados em A, B, C e H. 


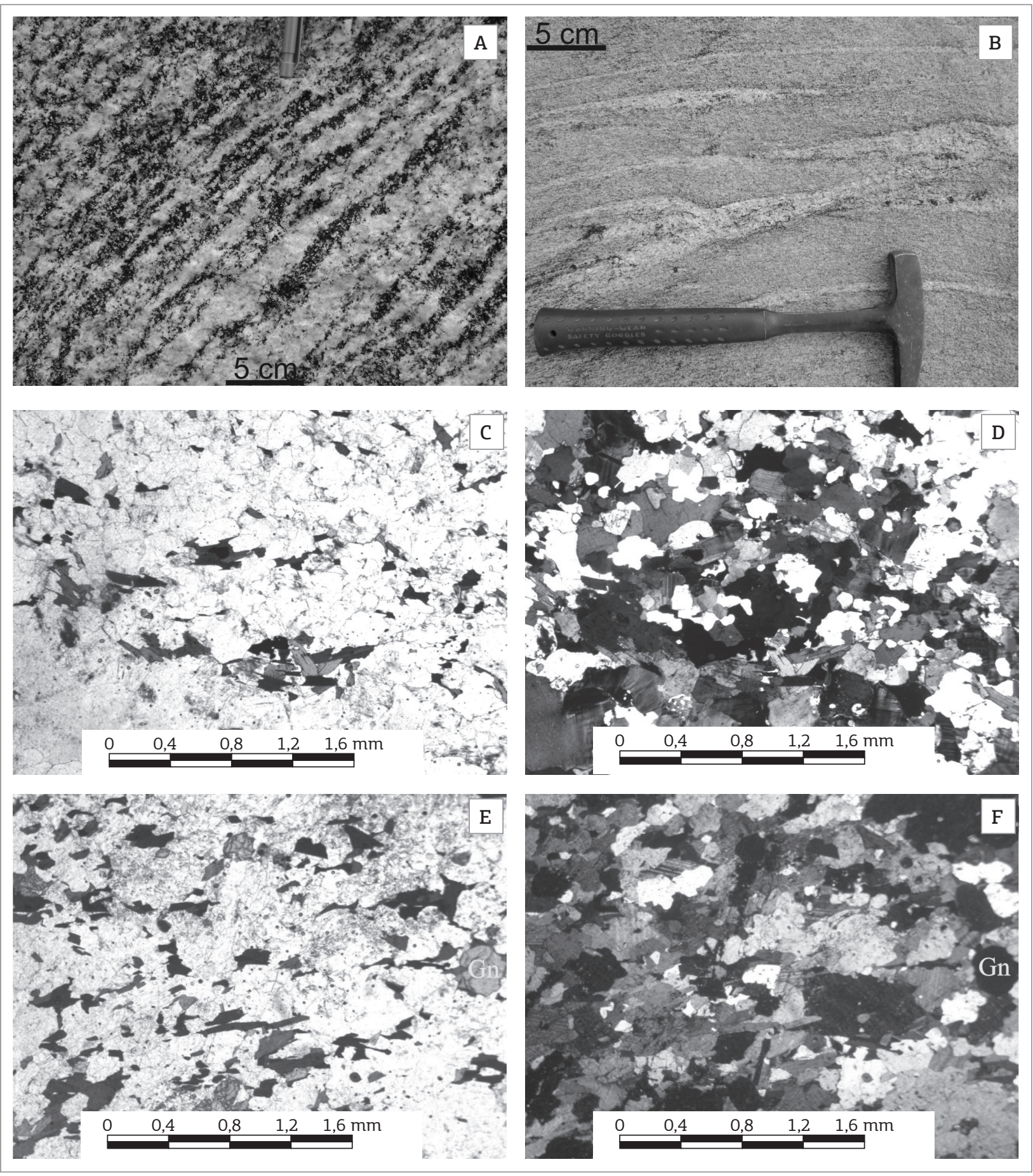

Figura 6. (A) Aspecto do bandamento gnáissico no anfibólio-biotita gnaisse; (B) feição do bandamento no granada-anfibólio-biotita gnaisse; (C e D) Fotomicrografias do anfibólio-biotita gnaisse ilustrando o alinhamento dos cristais de biotita associados à textura granoblástica; (E e F) Fotomicrografias do granada-anfibólio-biotita gnaisse destacando o alinhamento félsico e máfico com cristais de granada (Gn) associados às palhetas de biotita. Polarizadores paralelos à esquerda e cruzados à direita.

Os cristais de granada apresentam-se bastante fraturados e não exibem inclusôes indicativas de orientação interna.

A intensa ação da segunda fase de deformação $F_{2}$ determina uma acentuada reorientaçáo do bandamento gnáissico $S_{1}$ provocando seu dobramento e transposição ao longo de superfícies discretas de cisalhamentos dúcteis. $\mathrm{O}$ estereograma para polos da foliação $S_{1}$ mostra a orientação dominante das medidas em torno de 
N45-75W com mergulhos variando de $65^{\circ}$ a $85^{\circ}$ para NE e SW (Fig. 7). A superfície envoltória das dobras $\mathrm{D}_{2}$ apresenta orientação preferencial entre N30-70E como ilustrado nas Figs. 8A e B.

\section{Segunda fase de deformação}

A segunda fase de deformação $\left(\mathrm{F}_{2}\right)$ é responsável pela formaçáo de um acervo de estruturas tectônicas que indicam um evento de deformaçáo dominado pelo comportamento dúctil das rochas afetadas. Foram identificadas as seguintes estruturas nesta fase de deformação: dobras $D_{2}$, foliação $S_{2}$, lineaçóes $\mathrm{L}_{2}$ e bandas de cisalhamentos discretas relacionadas

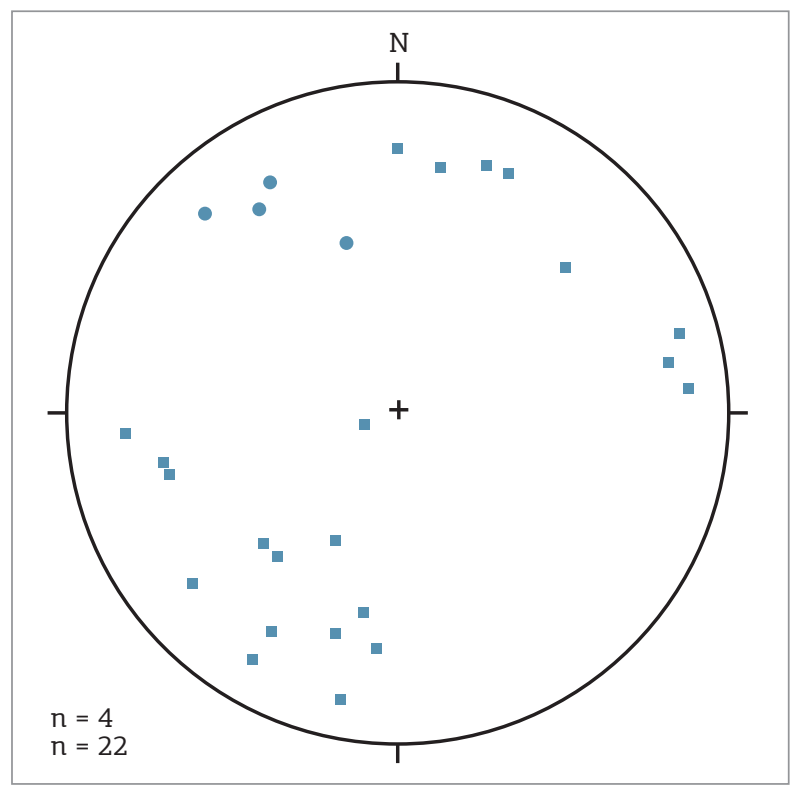

Figura 7. Estereograma para polos das atitudes dos flancos das dobras (quadrado) e atitudes das linhas de charneira (circulo), diagrama de igual-área, hemisfério inferior. às superfícies de transposição. As dobras $\mathrm{D}_{2}$ são apertadas a isoclinais comumente rompidas, classificadas de acordo com Fleuty (1964) como sendo dobras inclinadas com caimento e são marcadas pela reorientação do bandamento gnáissico. Em relação à foliação $S_{1}$, essa nova foliação $S_{2}$ é ortogonal nas zonas de charneira das dobras, comumente rompidas e paralelas nos flancos e orienta-se principalmente segundo a direção $\mathrm{N} 30$ - 60W com mergulhos altos variando entre $75^{\circ}$ e $85^{\circ}$ para os quadrantes NE e SW (Fig. 9).

A foliação $S_{2}$, do tipo xistosidade, é plano-axial às dobras $\mathrm{D}_{2}$ (Figs. 10A e B) e, pela forte transposição que reorienta o bandamento $\left(S_{1}\right)$, verifica-se o paralelismo entre

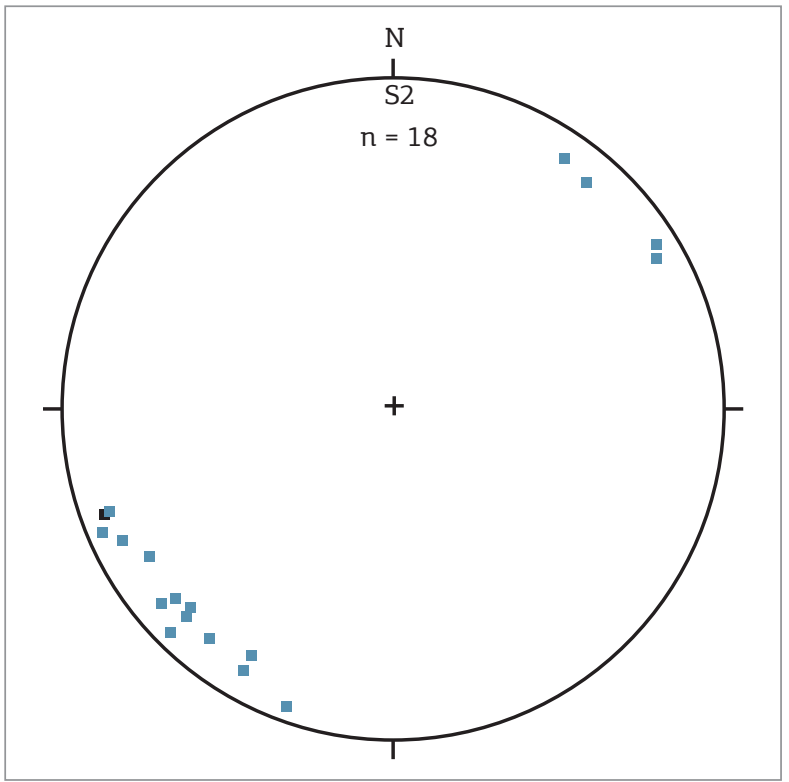

Figura 9. Estereograma para polos da foliação $S_{2}$, diagrama de igual-área, hemisfério inferior.

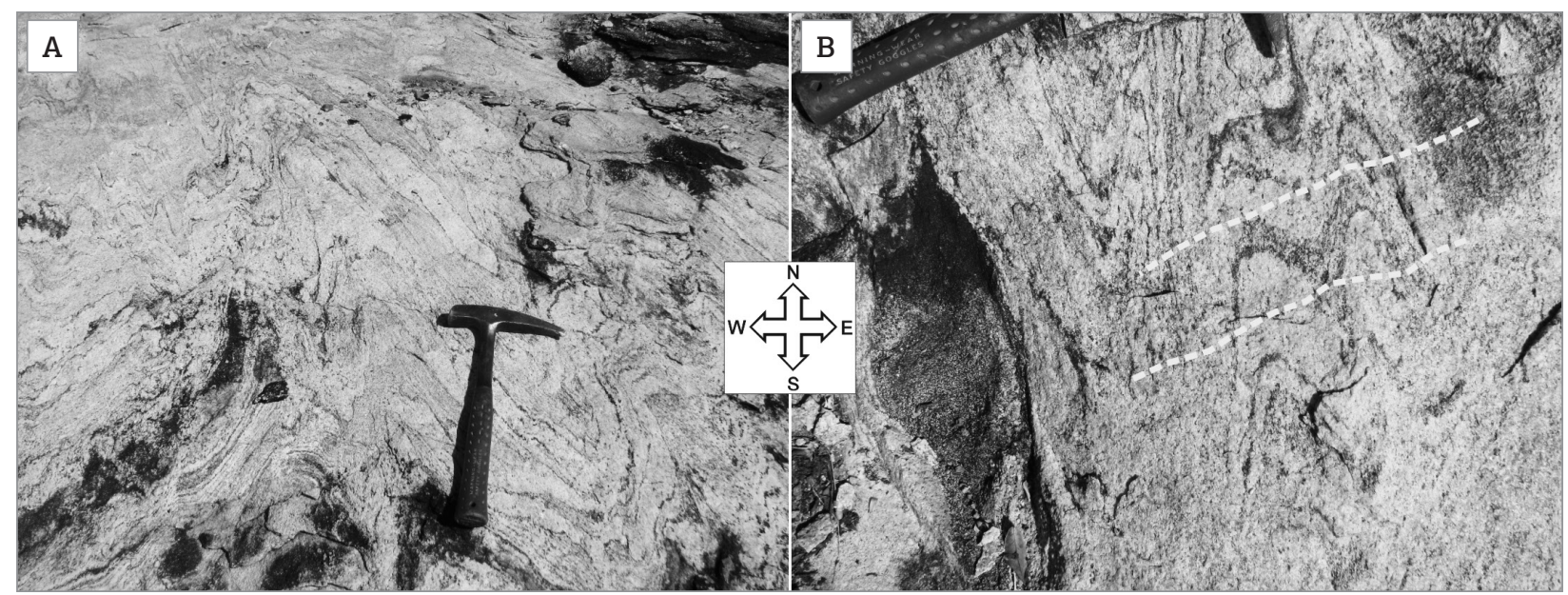

Figura 8. (A) Padrão de dobras apertadas a isoclinais; (B) padrão de atitude para a superfície envoltória das dobras com direção preferencial nordeste. 
as foliaçōes $S_{1}$ e $S_{2}$. (Figs. 10C e D). No granada-anfibóliobiotita gnaisse os porfiroblastos de granada ocorrem tanto nos níveis félsicos dobrados e transpostos por $\mathrm{F}_{2}$, quanto nas bandas mais escuras associados aos minerais máficos (Figs. 10E e F). As lineaçóes $\mathrm{L}_{2}$, definidas como eixo de microdobras $\mathrm{D}_{2}$ e lineação de estiramento e lineação mineral, são caracterizadas principalmente pelo alinhamento de minerais máficos e estiramento de cristais de quartzo e feldspato, visualizados nas linhas de charneira e nos flancos das dobras e apresentam caimento entre $15^{\circ}$ e $45^{\circ}$ no intervalo entre N16W e N8E.

O bloco diagrama apresentado na Fig. 11 ilustra as principais estruturas tectônicas observadas no Gnaisse Turvo, assim como os estereogramas, indicando a orientação preferencial das mesmas.

\section{GEOQUÍMICA}

A caracterização geoquímica do Gnaisse Turvo está fundamentada nos resultados analíticos de nove amostras selecionadas visando à abrangência das duas fácies petrográficas identificadas, sendo seis amostras da fácies anfibólio-biotita gnaisse e três da fácies granada-anfibólio-biotita gnaisse. Essas amostras foram selecionadas de forma a não conter fraturas ou veios, bem como não apresentarem indícios petrográficos e químicos de alteração hidrotermal/intempérica, mostrando valores de perda ao fogo, em geral, menores do que $1 \%$ em peso. Os dados litoquímicos estão dispostos na Tab. 2 e foram obtidos no Analytical Laboratories (ACMELAB), Canadá, pelos métodos de ICP-ES e ICP-MS para todos os elementos maiores e alguns menores e traços.

Nos diagramas de Harker, observa-se que rochas do Gnaisse Turvo caracterizam-se como ácidas, com valores de $\mathrm{SiO}_{2}$ entre 66,74 e $75,13 \%$, e que o comportamento da maioria dos elementos maiores, expressos em óxidos $\left(\mathrm{Al}_{2} \mathrm{O}_{3}, \mathrm{Fe}_{2} \mathrm{O}_{3}, \mathrm{CaO}, \mathrm{MgO}, \mathrm{TiO}_{2}\right.$ e $\left.\mathrm{P}_{2} \mathrm{O}_{5}\right)$ e dos traços $\mathrm{V}$ e Y (em ppm), em relação à sílica, indicam uma evolução normal com discretas correlaçóes lineares negativas sugerindo cristalização fracionada com empobrecimento em plagioclásio, hornblenda, apatita e óxidos de Fe-Ti como ilmenita e titanita. Em relação aos álcalis não se observa resultado entre o índice de diferenciação utilizado e o $\mathrm{Na}_{2} \mathrm{O}$, no entanto percebe-se uma tendência de correlação positiva com o $\mathrm{K}_{2} \mathrm{O}$, sugerindo que a evolução pode se caracterizar também por enriquecimento em feldspato potássico e biotita (Fig. 12).

Geoquimicamente, as rochas da unidade estudada classificam-se como de composição granodiorítica e granítica em diagramas que utilizam parâmetros diversos, tais como, álcalis versus sílica (Fig. 13A; Le Bas et al. 1986),
R1 X R2 (Fig. 13B; La Roche 1980) e $\mathrm{SiO}_{2}$ versus $\mathrm{Zr} / \mathrm{TiO}_{2}$ (Fig. 13C; Winchester \& Floyd 1977).

Os diagramas $\mathrm{Na}_{2} \mathrm{O}+\mathrm{K}_{2} \mathrm{O}$ versus $\mathrm{SiO}_{2}$ e AFM propostos por Irvine e Baragar (1971) sugerem que o magmatismo que originou os protólitos do Gnaisse Turvo sejam de afinidades, respectivamente, subalcalina e calcioalcalina (Figs. 14A e B), mostrando neste último uma evoluçáo marcada por enriquecimento em álcalis, com uma amostra do granada-anfibólio-biotita gnaisse discretamente deslocada para o campo toleítico devido a um incremento de ferro total em processos pós-magmáticos, provavelmente associados à neoformação de cristais de granada ricos em ferro (almandina). A natureza calcioalcalina do magmatismo responsável pelas rochas da unidade estudada é evidenciada também pelo diagrama de Peacock (1931) que utiliza, além dos álcalis, os valores de $\mathrm{CaO}$ (Fig. 14C); pelos valores de $\mathrm{Zr} / \mathrm{Y}$ geralmente maiores do que sete, ilustrados no gráfico $\mathrm{Zr}$ versus $\mathrm{Y}$ proposto por Barret e MacLean (1999; Fig. 14D); bem como através do diagrama de Le Maitre (1989; Fig. 14E) com todos os pontos que representam as rochas analisadas distribuindo-se no domínio da série de alto-K com grau de diferenciação bem marcado separando as amostras menos diferenciadas daquelas com teor de sílica maior consideradas como as mais evoluídas. Vale ressaltar que o deslocamento das duas amostras do granada-anfibólio-biotita gnaisse para o limite dos campos transicional/toleítico na Fig. 14D, provocado pelo incremento do teor de Y, está relacionado com a presença dos porfiroblastos de granada. No diagrama de Maniar e Piccoli (1989), os pontos que representam os litotipos do Gnaisse Turvo se posicionam no limite dos domínios definidos por estes autores para termos metaluminosos e peraluminosos, sugerindo uma filiação levemente peraluminosa para os protólitos das rochas estudadas (Fig. 14F). Este caráter peraluminoso é visto também em duas amostras portadoras de granada da série piralspita (possivelmente almandina), sendo atribuído à presença destes porfiroblastos o maior índice de saturação em alumina para esta variação petrográfica do Gnaisse Turvo.

Os resultados dos elementos terras raras (ETR) das amostras do Gnaisse Turvo normalizados pelos valores condríticos de Nakamura (1977), e ilustrados separadamente nas duas fácies previamente identificadas (Figs. 15A e B), evidenciam um forte fracionamento de ETR pesados (ETRP) em relação aos ETR leves (ETRL). É nítida a correlação entre o conteúdo de sílica e as razóes $(\mathrm{La} / \mathrm{Yb})_{\mathrm{N}}$ do conjunto analisado, bem como se observa que o aumento desse óxido (que expressa a diferenciação magmática em suítes graníticas) é proporcional ao aumento dessa razão, constatando-se dessa maneira, que os litotipos da fácies 

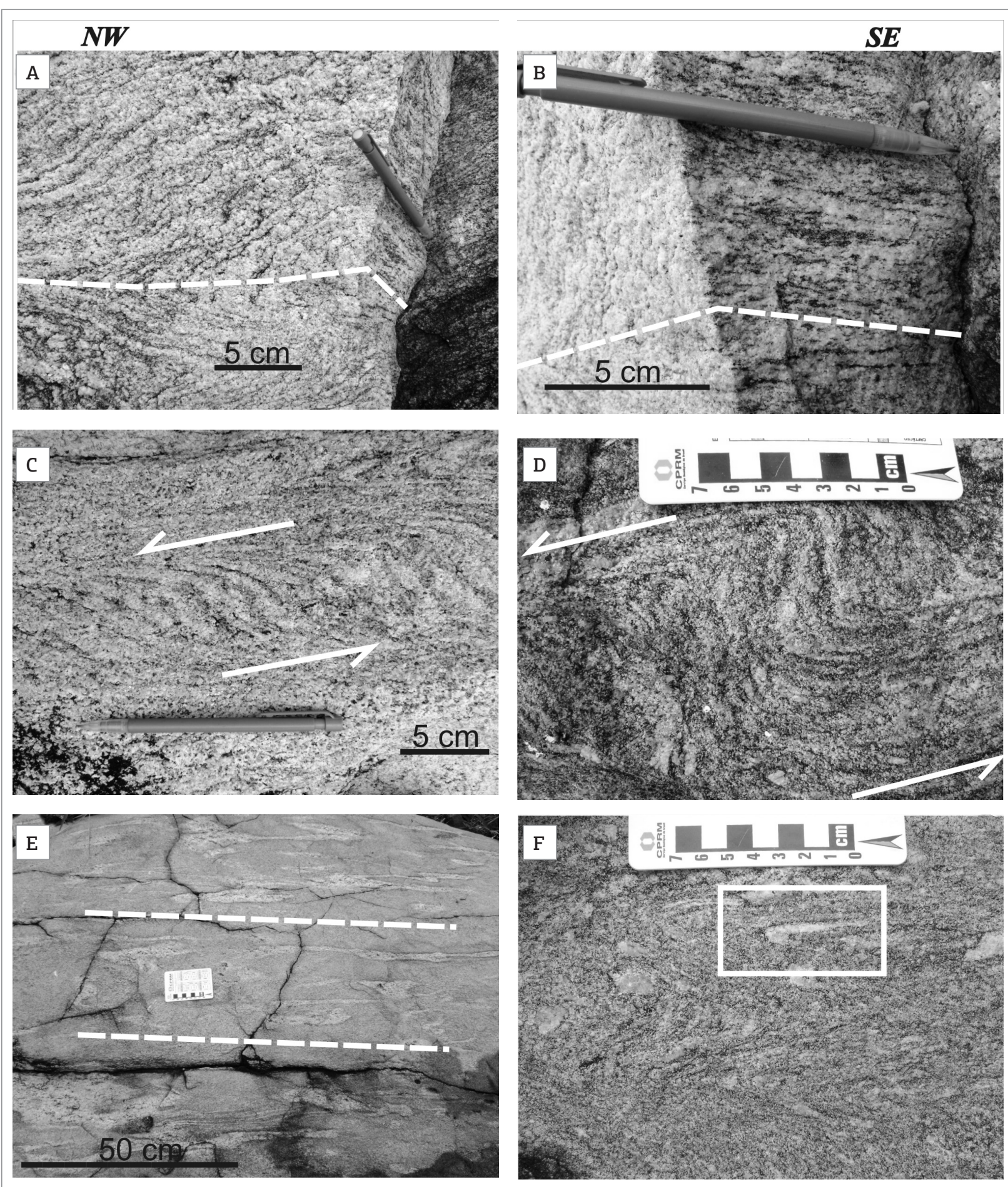

Figura 10. Fotos orientadas ( $A$ a D) em planta, (E) em corte subvertical e (F) em planta. (A e B) Caráter planoaxial da foliação $\mathrm{S}_{2}$; (C) zonas de cisalhamento sinistrais no anfibólio-biotita gnaisse; (D) zonas de cisalhamento sinistrais no granada-anfibólio-biotita gnaisse; (E) níveis félsicos estirados, dobrados e transpostos representando a foliação $S_{2}$; (F) detalhe da feição em "cabo de guarda chuva".

granada-anfibólio-biotita gnaisse, de composição granodiorítica $\left(\mathrm{SiO}_{2}\right.$ entre 66,74 e 69,25), têm razóes $(\mathrm{La} / \mathrm{Yb})_{\mathrm{N}}$ entre 5,29 e 11,62 (Fig. 15A); enquanto que, os da fácies anfibólio-biotita gnaisse, considerada mais diferenciada
$\left(\mathrm{SiO}_{2}\right.$ entre 72,58 e 75,13), apresentam razões $(\mathrm{La} / \mathrm{Yb})_{\mathrm{N}}$ bem maiores variando entre 11,64 e 20,58 (Fig. 15B). Isso sugere que as amostras estudadas correspondam a protólitos cogenéticos com evolução a partir de processos de 


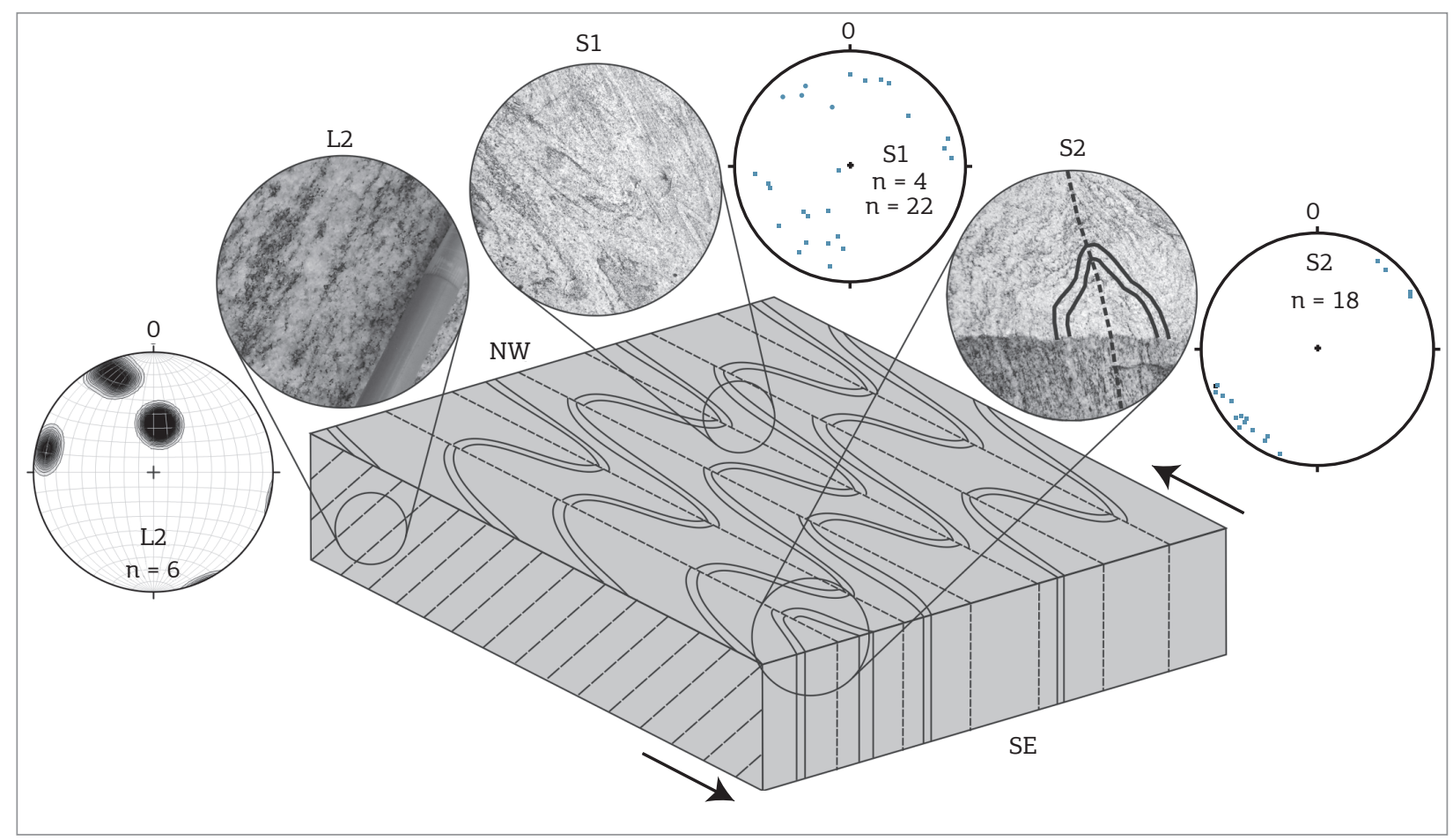

Figura 11. Bloco diagrama ilustrando o padrão estrutural do Gnaisse Turvo, destacando as principais estruturas tectônicas e os respectivos estereogramas.

cristalização fracionada com padróes de ETR semelhantes aos de séries calcioalcalina. Independentemente do tipo faciológico, apenas três amostras apresentam pronunciadas anomalias negativas de $\mathrm{Eu}$ (razóes $\mathrm{Eu} / \mathrm{Eu}^{*}$ entre 0,54 e 0,58 ) e todas as outras mostram fracas anomalias negativas de Eu com razóes $\mathrm{Eu} / \mathrm{Eu}^{*}$ entre 0,71 e 0,93, sugerindo para essas últimas diferenciação sem envolvimento importante de plagioclásio. Alguns elementos traços, estudados em base a normalização de seus teores, associados aos dados de $\mathrm{K}_{2} \mathrm{O}$, contra os valores dos granitos de cordilheira mesoceânica de Pearce, Harris e Tindle (1984; Figs. 15C e D) evidenciam, para ambas as fácies, um enriquecimento dos elementos litófilos de íons grandes (LILE), principalmente Rb, Ba e Th em relação aos de alta carga (HFSE) Ta, $\mathrm{Nb}, \mathrm{Ce}, \mathrm{Hf}, \mathrm{Zr}, \mathrm{Sm}, \mathrm{Y}$ e Yb. Observa-se também que, excetuando o Ce, os HFSE apresentam valores normalizados, em geral inferiores a 1, feição típica de magmatismo calcioalcalino de alto-K (Scheepers 1995) como os granitoides de arco magmático da Cordilheira dos Andes.

Para caracterização da ambiência tectônica dos protólitos do Gnaisse Turvo foram utilizados os diagramas $\mathrm{Nb}$ versus $\mathrm{Y}$ e $\mathrm{Rb}$ versus $\mathrm{Y}+\mathrm{Nb}$ de Pearce (1984; Figs. 16A e B) que indicam geraçáo em arco magmático corroborada pelo diagrama Hf-Rb/30-Ta*3 proposto por Harris, Pearce \& Tindle (1986; Fig. 16C).

\section{GEOCRONOLOGIA}

\section{Metodologia $\mathrm{Pb}-\mathrm{Pb}$ em evaporação de zircão}

O método de evaporação de chumbo em monocristais de zircão foi utilizado com o propósito de definir a idade de formação dos protólitos do Gnaisse Turvo. Os cristais de zircão foram extraídos da amostra após britagem, moagem e peneiramento, pré-concentração por elutriação, posterior separação com o emprego de líquido denso (bromofórmio) e separador magnético isodinâmico Frantz. A seleção dos cristais de zircáo foi realizada com o auxílio de lupa binocular e utilizou-se o intervalo entre 0,125 e $0,250 \mathrm{~mm}$. Os procedimentos relatados foram realizados no Laboratório de Preparação de Amostras para Estudos Geocronológicos e Isotópicos da Universidade Federal de Mato Grosso. Uma segunda fase, realizada no Laboratório de Geologia Isotópica (Pará-Iso) da Universidade Federal do Pará, consistiu na obtenção de fotomicrografias e seleção de cristais de zircão em microscópio petrográfico. Para $\mathrm{a}$ análise $\mathrm{Pb}-\mathrm{Pb}$ em zircão foi empregada a técnica de filamento duplo proposta por Kober $(1986,1987)$, a qual utiliza a razão ${ }^{207} \mathrm{~Pb} /{ }^{206} \mathrm{~Pb}$ para determinar a idade do cristal de zircão. Os dados foram obtidos utilizando-se o contador de íons do espectrômetro Finnigan MAT 262. A intensidade 
Tabela 2. Composição química de elementos maiores, menores (\% em peso), traços (ppm) de rochas do Gnaisse Turvo

\begin{tabular}{|c|c|c|c|c|c|c|c|c|c|}
\hline $\begin{array}{l}\text { Amostras } \\
\text { Elementos }\end{array}$ & AT40 & AT41 & AT43 & АT50 & AT50A & FL83 & FL91 & PA03 & PA03A \\
\hline $\mathrm{SiO}_{2}$ & 74,09 & 69,25 & 73,84 & 66,74 & 67,04 & 75,13 & 72,58 & 72,81 & 72,8 \\
\hline $\mathrm{TiO}_{2}$ & 0,3 & 0,41 & 0,31 & 0,74 & 0,91 & 0,22 & 0,31 & 0,18 & 0,16 \\
\hline $\mathrm{Al}_{2} \mathrm{O}_{3}$ & 13,36 & 14,85 & 12,92 & 15,09 & 13,73 & 12,85 & 13,7 & 13,91 & 14,02 \\
\hline $\mathrm{Fe}_{2} \mathrm{O}_{3(\mathrm{~T})}$ & 2,03 & 3,63 & 2,63 & 5,85 & 7,72 & 1,21 & 2,1 & 1,85 & 1,43 \\
\hline $\mathrm{MnO}$ & 0,05 & 0,07 & 0,06 & 0,1 & 0,11 & 0,04 & 0,05 & 0,05 & 0,04 \\
\hline $\mathrm{MgO}$ & 0,32 & 0,73 & 0,41 & 1,5 & 1,8 & 0,29 & 0,54 & 0,36 & 0,33 \\
\hline $\mathrm{CaO}$ & 1,46 & 2,79 & 1,58 & 2,96 & 2,36 & 1,02 & 1,84 & 1,95 & 1,88 \\
\hline $\mathrm{Na}_{2} \mathrm{O}$ & 3,87 & 3,81 & 3,17 & 2,85 & 2,36 & 2,72 & 3,26 & 3,54 & 3,52 \\
\hline $\mathrm{K}_{2} \mathrm{O}$ & 3,83 & 3,38 & 4,38 & 3,25 & 3,49 & 5,54 & 4,48 & 4,23 & 4,3 \\
\hline $\mathrm{P}_{2} \mathrm{O}_{5}$ & 0,05 & 0,14 & 0,09 & 0,12 & 0,07 & 0,04 & 0,09 & 0,05 & 0,05 \\
\hline $\mathrm{LOI}^{25}$ & 0,3 & 0,5 & 0,3 & 0,5 & 0,1 & 0,7 & 0,8 & 0,8 & 1,1 \\
\hline Total & 99,65 & 99,57 & 99,66 & 99,68 & 99,71 & 99,79 & 99,79 & 99,71 & 99,67 \\
\hline Sc & 4 & 14 & 6 & 16 & 20 & 3 & 3 & 4 & 4 \\
\hline $\mathrm{Ba}$ & 1849 & 2189 & 1271 & 778 & 734 & 830 & 759 & 1184 & 1225 \\
\hline $\mathrm{Be}$ & 2 & 3 & 1 & 2 & 1 & 1 & 2 & 1 & 2 \\
\hline Co & 36,9 & 40,1 & 86,2 & 91,4 & 91,0 & 95,2 & 95,9 & 71,7 & 153,6 \\
\hline Cs & 0,3 & 0,4 & 0,4 & 3,4 & 4,3 & 1,8 & 1,2 & 0,5 & 0,5 \\
\hline $\mathrm{Ga}$ & 14,3 & 16,1 & 13,7 & 19,9 & 16,8 & 11,4 & 12,8 & 12,3 & 12,9 \\
\hline $\mathrm{Hf}$ & 6,7 & 8,1 & 6,0 & 6,7 & 5,3 & 4,7 & 4,9 & 3,3 & 3,8 \\
\hline $\mathrm{Nb}$ & 9,9 & 5,9 & 7,8 & 13,5 & 17,2 & 7,7 & 7,6 & 4,4 & 4,4 \\
\hline $\mathrm{Rb}$ & 101,6 & 92,1 & 131,0 & 161,7 & 178,5 & 181,1 & 132,9 & 120,0 & 110,7 \\
\hline $\mathrm{Sn}$ & 1 & 1 & 1 & 3 & 4 & 1 & 1 & 1 & 1 \\
\hline $\mathrm{Sr}$ & 162,9 & 307,2 & 177,6 & 149,8 & 118,8 & 202,4 & 196,4 & 217,5 & 218,3 \\
\hline $\mathrm{Ta}$ & 0,8 & 0,3 & 0,6 & 0,9 & 1,1 & 0,8 & 0,6 & 0,5 & 0,6 \\
\hline Th & 19,6 & 6,5 & 18,5 & 20,7 & 10,5 & 13,5 & 18,6 & 10,2 & 9,2 \\
\hline $\mathrm{U}$ & 0,9 & 0,6 & 0,6 & 2,0 & 1,1 & 1,6 & 0,6 & 0,9 & 0,7 \\
\hline V & 16 & 26 & 15 & 96 & 106 & 15 & 26 & 16 & 135,2 \\
\hline $\mathrm{W}$ & 225,6 & 218,2 & 485,5 & 472,8 & 469,5 & 489,4 & 487,3 & 427,4 & 801,9 \\
\hline $\mathrm{Zr}$ & 238,5 & 314,0 & 217,8 & 255,6 & 176,7 & 151,3 & 171 & 131,4 & 135,2 \\
\hline $\mathrm{Y}$ & 31,3 & 26 & 32,6 & 51,2 & 41,4 & 19,2 & 22,3 & 20,0 & 17,5 \\
\hline Mo & 0,4 & 0,4 & 0,4 & 0,5 & 8,8 & 0,2 & 0,2 & 0,2 & 1,9 \\
\hline $\mathrm{Cu}$ & 2,8 & 7,5 & 2,1 & 19,0 & 21,6 & 0,4 & 6,2 & 1,8 & 3,2 \\
\hline $\mathrm{Pb}$ & 3,4 & 2,0 & 3,8 & 3,1 & 3,0 & 3,3 & 3,2 & 4,0 & 3,9 \\
\hline $\mathrm{Zn}$ & 20 & 50 & 31 & 62 & 70 & 16 & 25 & 20 & 20 \\
\hline $\mathrm{Ni}$ & 6,5 & 3,1 & 3,2 & 15,5 & 56,0 & 1,6 & 4 & 4,4 & 12,5 \\
\hline As & 0,5 & 0,5 & 0,5 & 0,5 & 0,5 & 0,5 & 0,5 & 0,5 & 0,5 \\
\hline $\mathrm{Sb}$ & 0,1 & 0,1 & 0,1 & 0,1 & 0,1 & 0,1 & 0,1 & 0,1 & 0,1 \\
\hline $\mathrm{Bi}$ & 0,1 & 0,1 & 0,1 & 0,1 & 0,1 & 0,1 & 0,1 & 0,1 & 0,1 \\
\hline $\mathrm{Ag}$ & 0,1 & 0,1 & 0,1 & 0,1 & 0,1 & 0,1 & 0,1 & 0,1 & 0,1 \\
\hline $\mathrm{Au}$ & 0,5 & 0,5 & 0,5 & 0,5 & 2,1 & 0,5 & 0,5 & 0,5 & 0,5 \\
\hline $\mathrm{Tl}$ & 0,1 & 0,1 & 0,1 & 0,3 & 0,4 & 0,1 & 0,1 & 0,1 & 0,1 \\
\hline $\mathrm{La}$ & 92,0 & 49,4 & 71,9 & 53,2 & 33,9 & 51,7 & 42,3 & 36,9 & 29,1 \\
\hline $\mathrm{Ce}$ & 189,2 & 102,5 & 147,4 & 115,1 & 78,0 & 97,9 & 86,7 & 71,2 & 55,0 \\
\hline $\operatorname{Pr}$ & 17,90 & 11,04 & 15,16 & 13,11 & 7,28 & 10 & 8,96 & 6,80 & 5,43 \\
\hline $\mathrm{Nd}$ & 54,8 & 40,6 & 49,5 & 46,6 & 27,0 & 31,9 & 30,5 & 22,5 & 18,5 \\
\hline Sm & 7,97 & 7,81 & 8,47 & 9,60 & 4,50 & 4,02 & 5,1 & 3,67 & 3,24 \\
\hline $\mathrm{Eu}$ & 2,00 & 2,22 & 1,38 & 1,60 & 1,12 & 0,8 & 0,89 & 0,86 & 0,88 \\
\hline Gd & 6,36 & 6,87 & 7,03 & 8,61 & 4,28 & 2,97 & 4,39 & 3,47 & 2,72 \\
\hline $\mathrm{Tb}$ & 0,94 & 1,04 & 1,05 & 1,43 & 0,85 & 0,45 & 0,7 & 0,56 & 0,47 \\
\hline Dy & 5,09 & 5,41 & 5,52 & 7,85 & 5,74 & 2,45 & 3,94 & 3,04 & 2,72 \\
\hline Ho & 1,04 & 1,19 & 1,13 & 1,72 & 1,41 & 0,51 & 0,76 & 0,68 & 0,59 \\
\hline $\mathrm{Er}$ & 3,16 & 3,24 & 3,02 & 5,01 & 4,22 & 1,55 & 2,15 & 2,11 & 1,80 \\
\hline $\mathrm{Tm}$ & 0,47 & 0,47 & 0,46 & 0,76 & 0,67 & 0,25 & 0,3 & 0,33 & 0,28 \\
\hline $\mathrm{Yb}$ & 2,98 & 2,83 & 2,63 & 4,87 & 4,27 & 1,74 & 1,75 & 2,03 & 1,67 \\
\hline $\mathrm{Lu}$ & 0,45 & 0,42 & 0,38 & 0,74 & 0,62 & 0,3 & 0,25 & 0,28 & 0,26 \\
\hline $\mathrm{Eu} / \mathrm{Eu}^{*}$ & 0,86 & 0,93 & 0,55 & 0,54 & 0,78 & 0,71 & 0,58 & 0,74 & 0,91 \\
\hline $\mathrm{La} / \mathrm{Yb}$ & 20,58 & 11,62 & 18,23 & 7,28 & 5,29 & 19,81 & 16,11 & 12,12 & 11,64 \\
\hline $\mathrm{Zr} / \mathrm{Y}$ & 7,61 & 12,07 & 6,68 & 4,99 & 4,26 & 7,88 & 7,66 & 6,57 & 7,72 \\
\hline $\mathrm{Rb} / \mathrm{Ba}$ & 0,05 & 0,04 & 0,1 & 0,2 & 0,24 & 0,21 & 0,17 & 0,1 & 0,09 \\
\hline
\end{tabular}




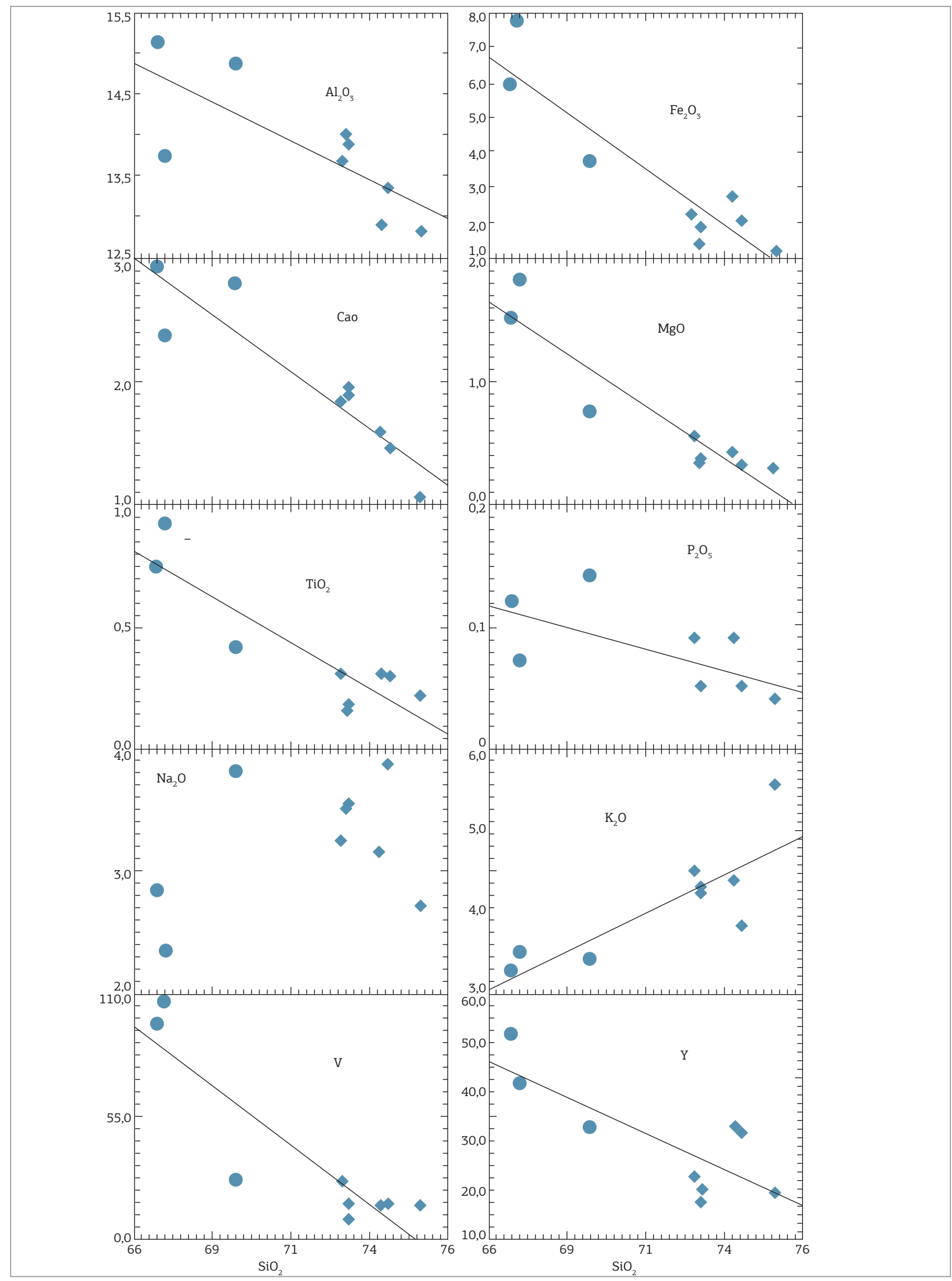

Figura 12. Diagramas de Harker para elementos maiores e traços das amostras do Gnaisse Turvo; os círculos representam amostras da fácies granada-anfibólio-biotita gnaisse e os losangos representam amostras da fácies anfibólio-biotita gnaisse. 


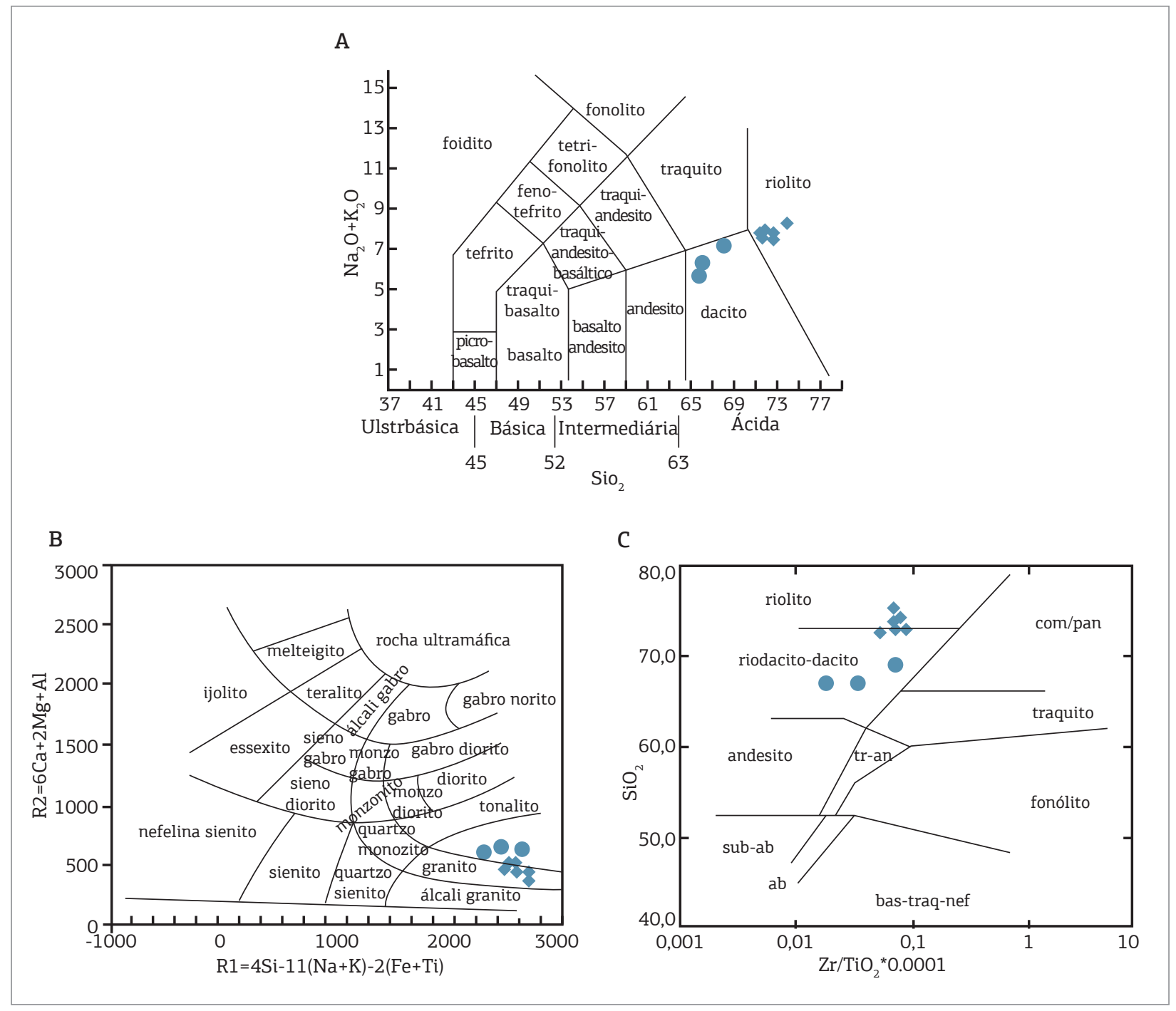

Figura 13. Diagramas de classificação de rocha para as amostras do gnaisse Turvo. (A) $\mathrm{Na}_{2} \mathrm{O}+\mathrm{K}_{2} \mathrm{O}$ versus $\mathrm{SiO}{ }_{2}$ (Le Bas et al. 1986); (B) R1 versus $\mathrm{R} 2$ (La Roche 1980); (C) $\mathrm{SiO}_{2}$ versus $\mathrm{Zr} / \mathrm{TiO}_{2}$ (Winchester \& Floyd 1977).

dos isótopos de $\mathrm{Pb}$ foi medida seguindo a sequência de massa 204, 206, 207 e 208, ao longo de varreduras que definem um bloco de dados com razóes ${ }^{207} \mathrm{~Pb} /{ }^{206} \mathrm{~Pb}$. A razão ${ }^{207} \mathrm{~Pb} /{ }^{206} \mathrm{~Pb}$ foi medida em três etapas de evaporação nas temperaturas de $1.450,1.500$ e $1.550^{\circ} \mathrm{C}$. As calibraçôes foram feitas usando o padrão NBS 983. A média das idades foi calculada segundo Gaudette et al. (1998) e os erros analíticos são apresentados com precisão de $2 \sigma( \pm 95 \%$ de precisão). As idades foram calculadas usando-se as constantes de decaimento e abundâncias isotópicas listadas por Steiger e Jäger (1977).

\section{Resultados analíticos}

Os grãos de zircão analisados do Gnaisse Turvo, amostra PA03, (coordenadas 795213, 8316019 UTM WGS 84; Fig. 3), foram extraídos da fácies anfibólio-biotita gnaisse. Os dados analíticos encontram-se na Tab. 3 e as características morfológicas dos grãos datados são apresentadas na Fig. 17A. Os grãos da amostra (PA03) exibem cor castanha, formas prismáticas e alongadas. Alguns cristais mostram bordas sobrecrescidas e outros zoneamento oscilatório e feiçôes de metamictização sendo descartados para análise, quando possível. Em dezoito cristais, quatro não emitiram $\mathrm{Pb}$ suficiente (cristais 4, 5, 6, 9), um apresentou razão ${ }^{204} \mathrm{~Pb} /{ }^{206} \mathrm{~Pb}$ superior a 0,0004 (1) e oito foram eliminados por apresentarem idade inferior $(10,11,12,13,15,16$, $17,18)$ provavelmente devido a metamictização que causa perda de $\mathrm{Pb}$ radiogênico. Foram analisados cinco cristais de zircão (2, 3, 7, 8 e 14), os quais forneceram idades aparentes ${ }^{207} \mathrm{~Pb} /{ }^{206} \mathrm{~Pb}$ entre $1649,9 \pm 3,4 \mathrm{Ma}$ e $1657,3 \pm 5,2 \mathrm{Ma}$, sendo a idade média de 1651,6 \pm 4,4 Ma calculada para estes cristais (Figs. 17A e B). A idade obtida foi interpretada como a época de formação do protólito ígneo do Gnaisse Turvo, concordando com a idade de colocação do corpo. 

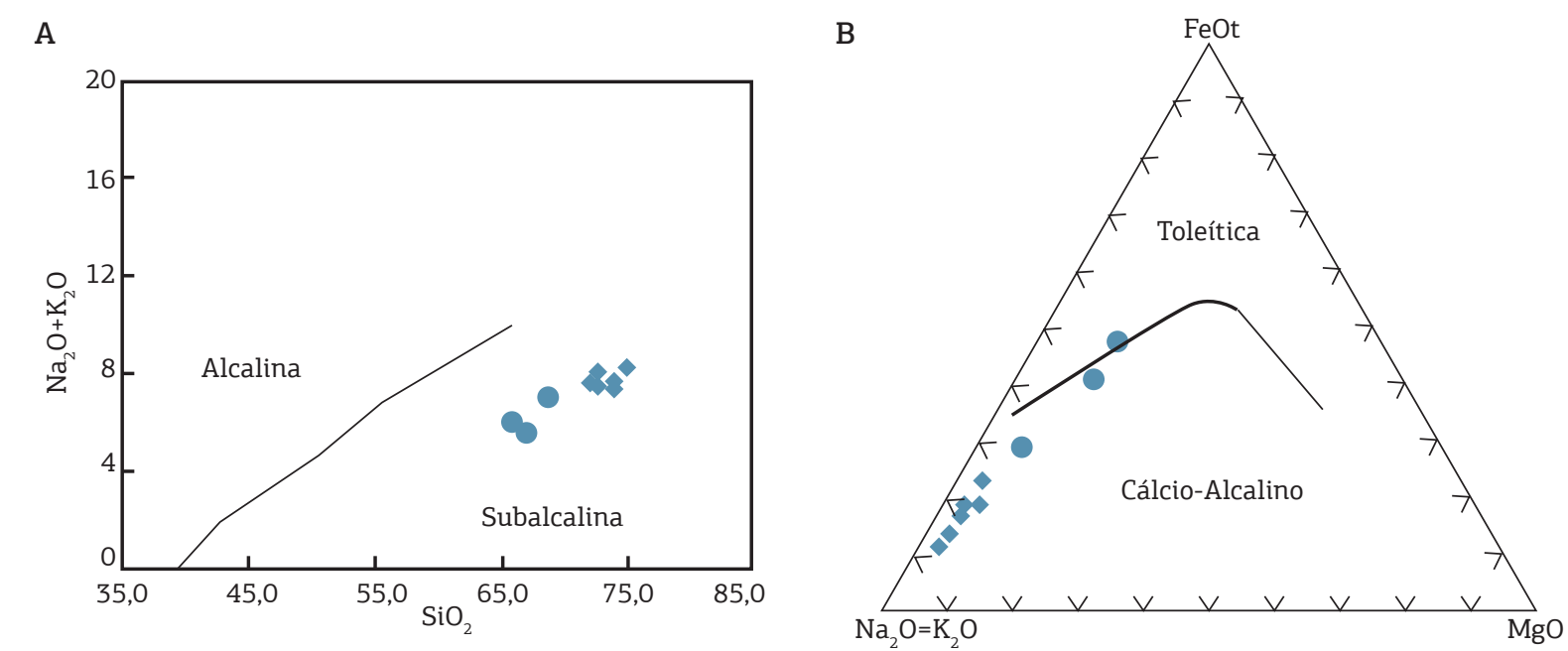

C

$\mathrm{D}$
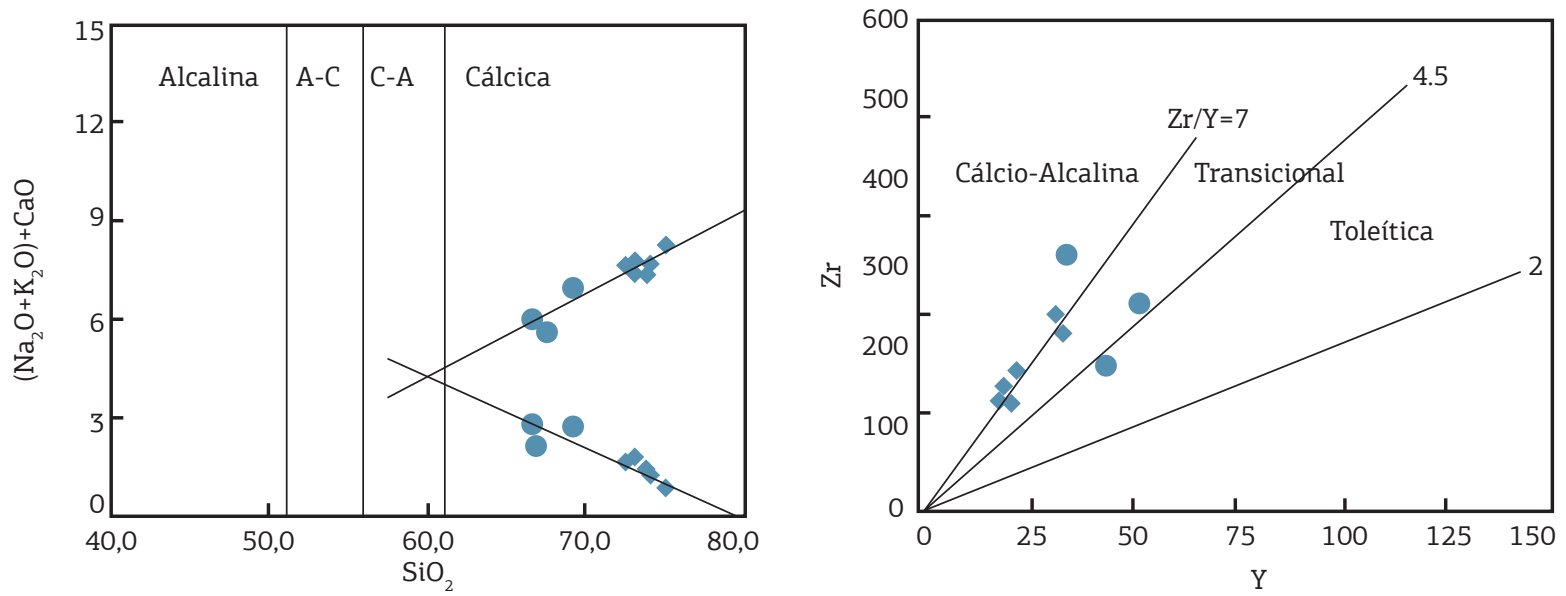

E

$\mathrm{F}$
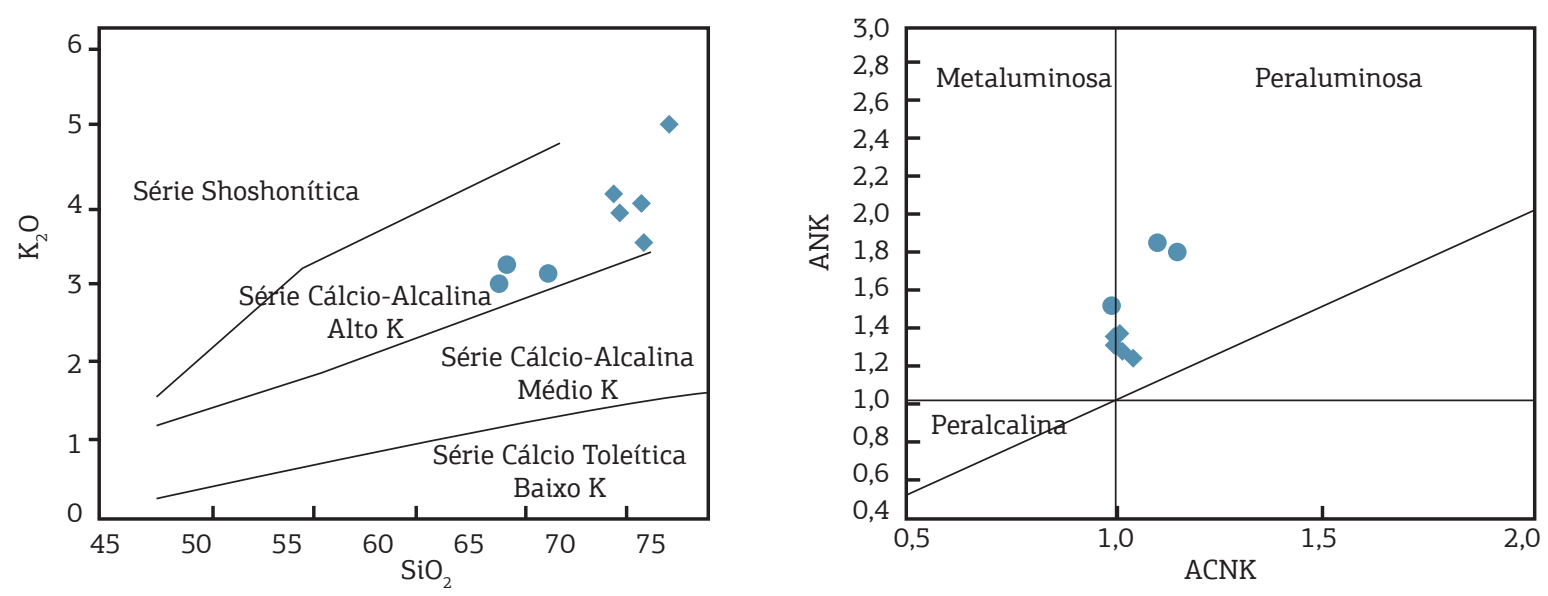

Figura 14. Diagramas classificatórios de séries magmáticas para as rochas do Gnaisse Turvo. (A e B) Álcalis versus sílica e AFM de (Irvine \& Baragar 1971); (C) $\mathrm{Na}_{2} \mathrm{O}+\mathrm{K}_{2} \mathrm{O}$ e CaO versus sílica (Peacock 1931); (D) Zr versus Y (Barret \& MacLean 1999); (E) K $\mathrm{K}_{2} \mathrm{O}$ versus sílica (Peccerillo \& Taylor 1976); (F) A/CNK versus A/NK (Maniar \& Piccoli 1989). 

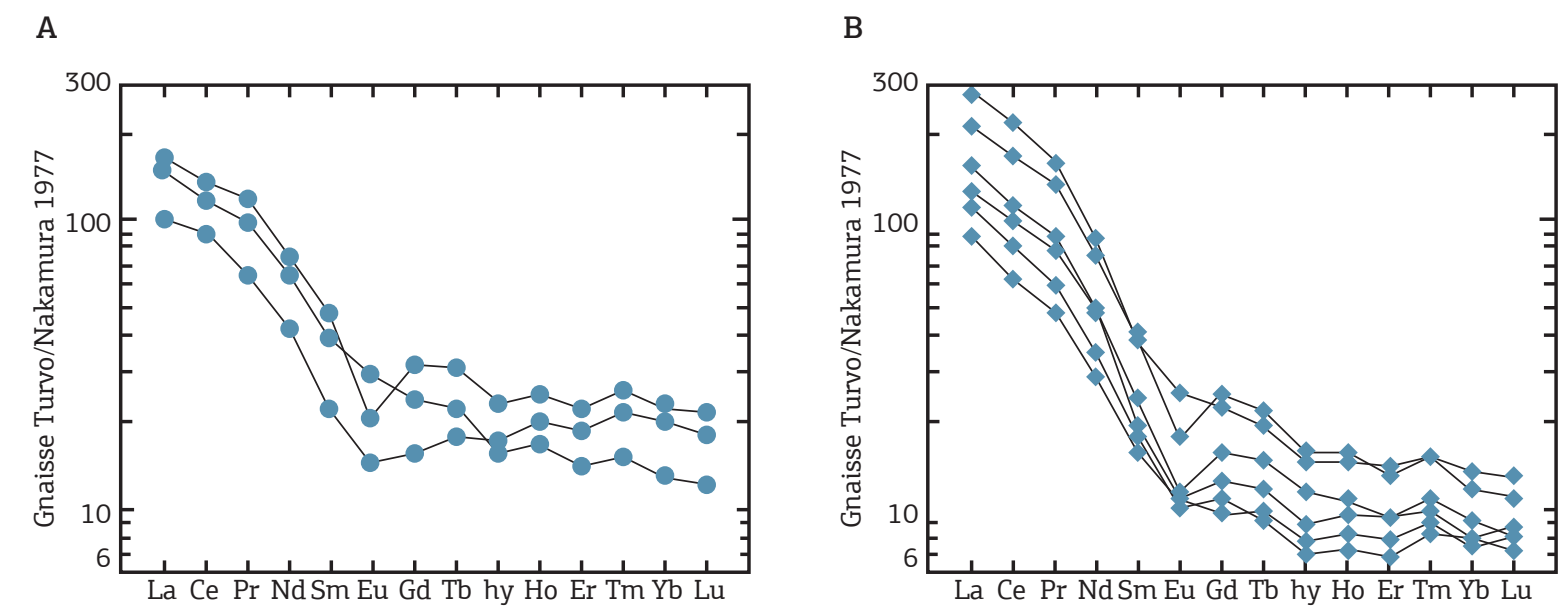

C

D
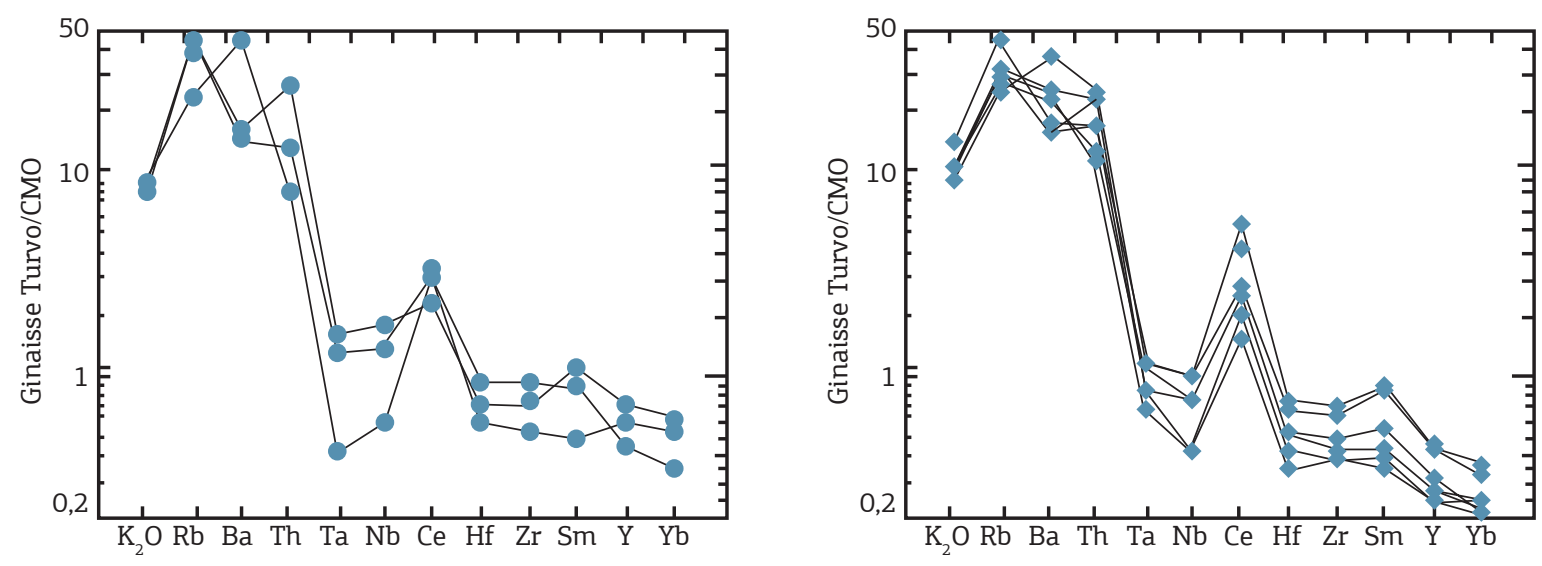

Figura 15. Padrões de distribuição dos elementos traço do Gnaisse Turvo nas fácies granada-anfibólio-biotita gnaisse e anfibólio-biotita gnaisse, respectivamente, à esquerda e à direita. (A e B) elementos terras raras normalizados pelos valores condríticos de Nakamura (1977). (C e D) Elementos traço e $\mathrm{K}_{2} \mathrm{O}$ normalizados pelos valores de granitos de cordilheira mesoceânica.

\section{DISCUSSÕES E CONCLUSÕES}

Situada no SW do Cráton Amazônico, a Província Rondoniana-San Ignácio, conforme definição de Ruiz (2009) e Bettencourt et al. (2010), é constituída por um amálgama de terrenos aglutinados ao longo de sucessivos episódios orogênicos no Mesoproterozoico. O Terreno Paraguá, inicialmente definido como Cráton Paraguá por Litherland et al. (1986), corresponde a vasta área que se estende do oriente boliviano até o oeste do estado de Mato Grosso, no Brasil, sendo delimitado a leste por remanescente de crosta oceânica representada pelo Terreno Rio Alegre (Geraldes 2000, Ruiz 2005, 2009, Bettencourt et al. 2010) e recoberta a oeste, norte e sul por sedimentos fanerozoicos. Desde o trabalho pioneiro de Litherland et al. (1986) até a recente revisão de Bettencourt et al. (2010), são reconhecidas as seguintes unidades litoestratigráficas no Terreno Paraguá: o embasamento paleoproterozoico composto pelo Complexo Gnáissico Chiquitania; o Complexo Granulítico Lomas Manechis; e o Grupo San Ignácio. As manifestaçôes ígneas mesoproterozoicas, relacionadas à Orogenia San Ignácio, são representadas pelo Complexo Granitoide Pensamiento e intrusivas menores associadas e completam o substrato do Grupo Aguapeí, depositado no período Esteniano. A Orogenia Sunsás (1,0 a 0,9 Ga) retrabalha parcialmente o Terreno Paraguá, nas áreas afetadas pelos cinturôes móveis Sunsás e Aguapeí, gerando metamorfismo de baixo grau e granitogênese de natureza ácida dominante. O Gnaisse Turvo corresponde a um corpo intrusivo alojado em uma associação de rochas ortoderivadas, como indicam os xenólitos de metagabros e anfibolitos e paraderivadas, 


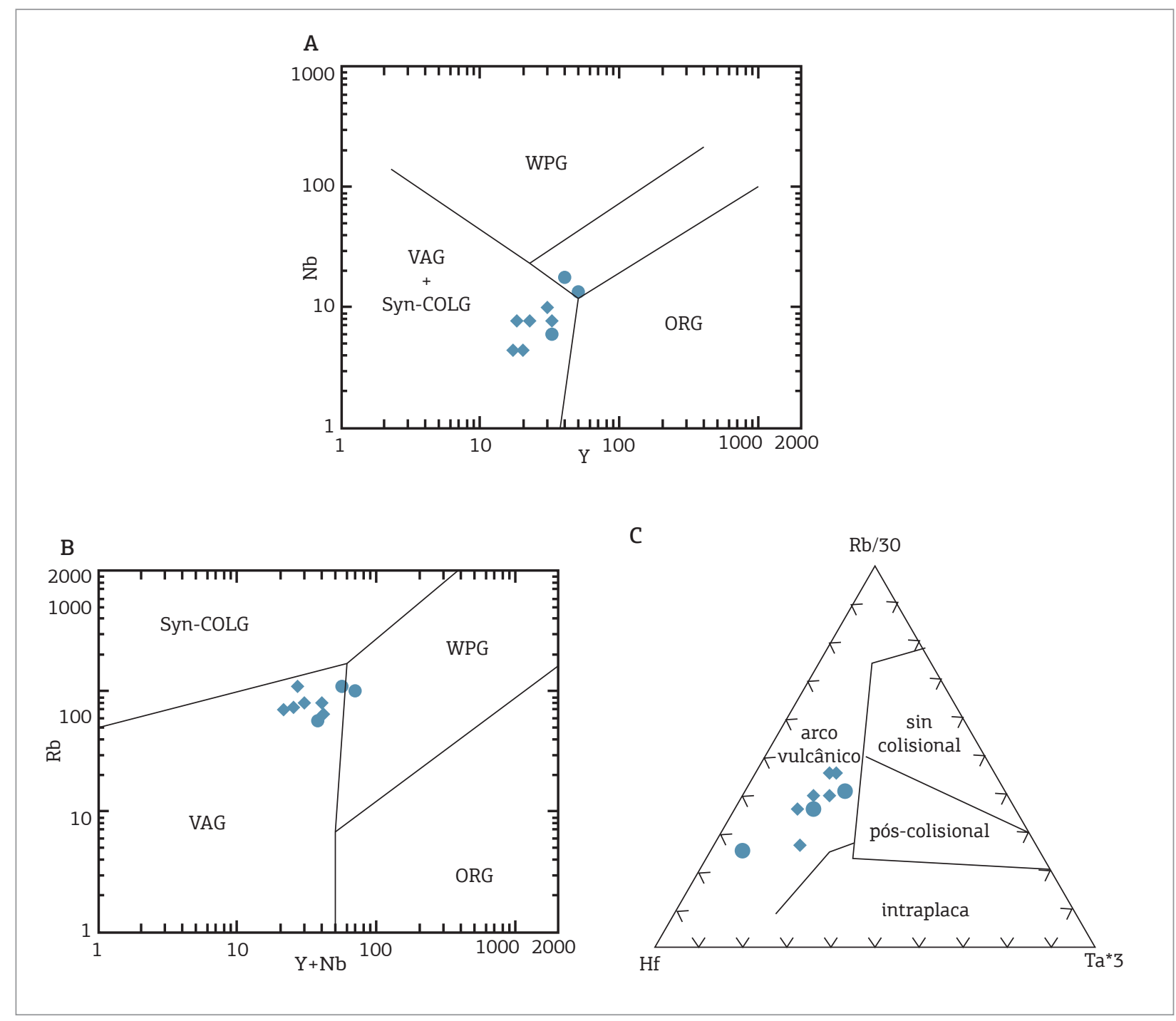

Figura 16. Diagramas de classificação tectônica para o Gnaisse Turvo. (A e B) Pearce, Harris e Tindle (1984); (C) Harris, Pearce e Tidle (1986).

Tabela 3. Resultados analíticos de evaporação de $\mathrm{Pb}$ em monocristais de zircão do Gnaisse Turvo. 0 erro analítico é calculado em $2 \sigma$

\begin{tabular}{|c|c|c|c|c|c|c|c|c|c|c|}
\hline Grão & $\begin{array}{l}\text { Temperatura de } \\
\text { evaporação }\left({ }^{\circ} \mathrm{C}\right)\end{array}$ & Razões & ${ }^{204} \mathrm{~Pb} /{ }^{206} \mathrm{~Pb}$ & $\begin{array}{c}\text { Desvio } \\
2 \sigma\end{array}$ & $\begin{array}{c}{ }^{208} \mathrm{~Pb} /{ }^{206} \mathrm{~Pb} \\
\text { (c) }\end{array}$ & $\begin{array}{c}\text { Desvio } \\
2 \sigma\end{array}$ & $\begin{array}{c}{ }^{207} \mathrm{~Pb} /{ }^{206} \mathrm{~Pb} \\
\text { (c) }\end{array}$ & $\begin{array}{c}\text { Desvio } \\
2 \sigma\end{array}$ & Idade & $\begin{array}{c}\text { Desvio } \\
2 \sigma\end{array}$ \\
\hline PA03 (2) & 1.550 & 40/106 & 0,000112 & 0,000002 & 0,12785 & 0,00216 & 0,10139 & 0,00018 & 1649 & \pm 3 \\
\hline PA03 (3) & 1.500 & $4 / 56$ & 0,000117 & 0,000004 & 0,11684 & 0,001 & 0,10132 & 0,00026 & 1648 & \pm 4 \\
\hline PA03 (7) & 1.450 & $30 / 38$ & 0,00008 & 0,00001 & 0,12167 & 0,0008 & 0,10163 & 0,00038 & 1654 & \pm 7 \\
\hline PA03 (8) & 1.500 & $6 / 48$ & 0,000059 & 0,000052 & 0,11803 & 0,00209 & 0,10157 & 0,00100 & 1653 & \pm 9 \\
\hline \multirow[t]{2}{*}{ PA03 (14) } & 1.500 & $30 / 68$ & 0,000072 & 0,000007 & 0,11936 & 0,0024 & 0,10179 & 0,00029 & 1657 & \pm 5 \\
\hline & & $110 / 630$ & & & & & & $\begin{array}{l}\text { Idade } \\
\text { Média }\end{array}$ & 1651 & \pm 4 \\
\hline
\end{tabular}

como os restos de uma sequência supracrustal constituída por granada quartzitos, sillimanita-granada gnaisses e granada gnaisses e exposta sob a forma de restritas faixas nas suas imediaçôes. A caracterização petrográfica do Gnaisse
Turvo permitiu a individualização de duas fácies: a mais abundante compreende a fácies anfibólio-biotita gnaisse e é formada por rochas leucocráticas, cinza-claro, bandadas, de granulação média a grossa, classificadas como granodioritos 


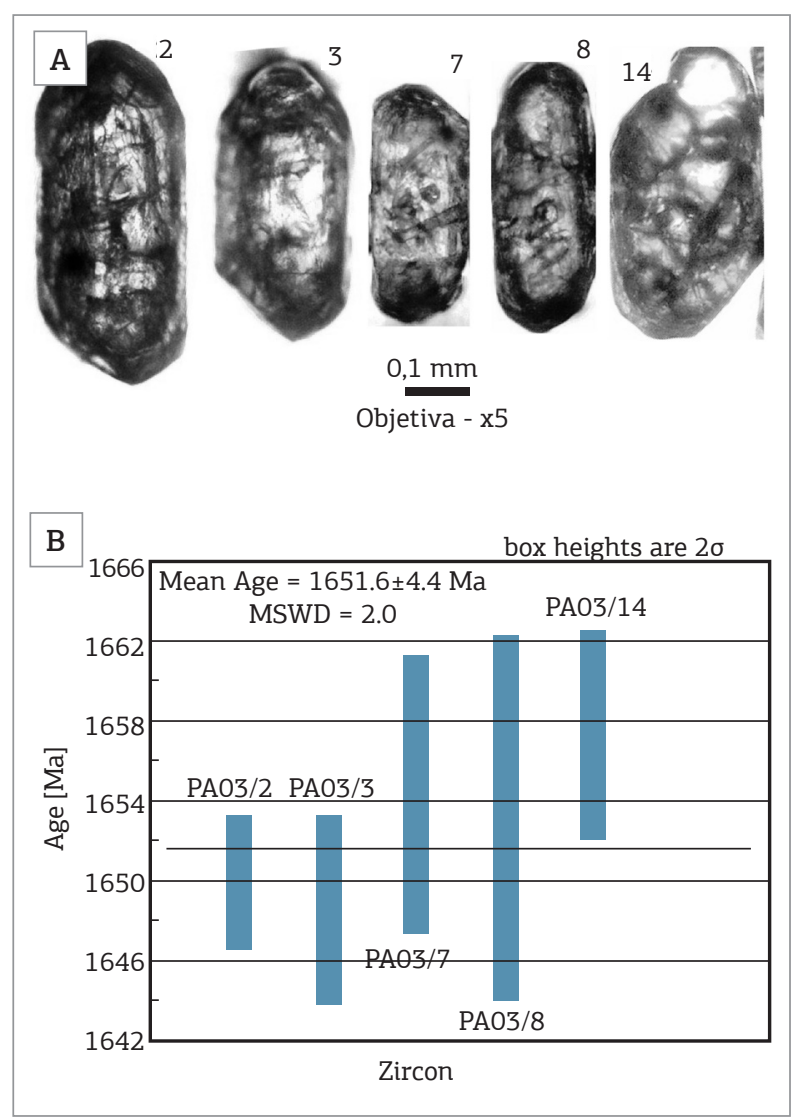

Figura 17. (A) Feição morfológica dos cristais de zircão datados. (B) Idade média dos cristais.

a sienogranitos, tendo biotita e hornblenda como minerais máficos principais. A outra, quantitativamente subordinada, corresponde à fácies granada-anfibólio-biotita gnaisse que é constituída por rochas meso a leucocráticas, cinza a cinza escuro, bandadas, de granulação média, composição granodiorítica e que apresentam como minerais máficos, além de biotita e anfibólio, cristais neoformados de granada. A paragênese constituída por quartzo + microclina/ ortoclásio + plagioclásio (oligoclásio) + hornblenda + biotita indica que os gnaisses estudados foram formados em um metamorfismo sob condiçôes de fácies anfibolito e a textura coronítica consistindo em porfiroblastos de granada com auréola de hornblenda identifica retrometamorfismo. Dissolução e reprecipitação de aglomerados microcristalinos de quartzo e feldspato e presença de mirmequita confirmam condiçóes de alta temperatura, segundo os critérios definidos por Vernon (1991). A superposição de estruturas tectônicas atesta a natureza policíclica do Gnaisse Turvo, cujo bandamento gnáissico $\left(S_{1}\right)$, definido pela alternância das bandas félsicas e máficas, formado durante a primeira fase de deformação, é intensamente dobrado e transposto pela segunda fase de deformação, de caráter dúctil, que gera mesodobras simétricas a assimétricas, inclinadas, com caimento variando entre $15^{\circ}$ e $45^{\circ}$ principalmente para NW. Esta fase gera foliação plano-axial do tipo xistosidade $\left(\mathrm{S}_{2}\right)$ que exibe direção N30 - 60W e mergulhos entre $75^{\circ} \mathrm{e}$ $85^{\circ}$ para NE e SW, bem como zonas de cisalhamentos estreitas e paralelas a $S_{2}$, com lineação de estiramento/mineral $\mathrm{L}_{2}$, sugerindo um movimento reverso, com pequeno componente oblíquo, ou direcional. A primeira fase de deformação e metamorfismo, responsável pela geração do bandamento gnáissico é atribuída à Orogenia Lomas Manechis, segundo a definiçáo de Boger et al. (2005) e corresponde às estruturas $\mathrm{Do}_{2}$ de Litherland et al. (1986); enquanto a fase de deformaçáo e metamorfismo mais jovem $\left(\mathrm{F}_{2}\right)$ é atribuída a Orogenia San Ignácio, a qual gera estruturas com orientação similar a foliação $S_{2}$ nos granitoides sin a tardi orogênicos como, por exemplo, os granitos Guaporeí e Passagem. As estruturas relacionadas à fase $\mathrm{F}_{2}$ no Gnaisse Turvo são correlacionáveis à deformação $\mathrm{Do}_{3}$ definida por Litherland et al. (1986). Apesar de se julgar necessário um maior adensamento de amostragem, o estudo geoquímico do Gnaisse Turvo sugere que as duas fácies identificadas correspondam a protólitos cogenéticos que representam uma sequência ácida, formada por um magmatismo calcioalcalino de alto-K, metaluminoso a peraluminoso principalmente no granada-anfibólio-biotita gnaisse, onde este caráter deve estar relacionado à presença de cristais de granada da série das piralspitas (almandina); sugere também, a colocação deste magmatismo em ambientes de arco magmático, tendo uma evolução através de processos de cristalização fracionada, com discreto empobrecimento em plagioclásio e minerais máficos primários, tais como hornblenda, óxidos de $\mathrm{Fe}-\mathrm{Ti}$ como ilmenita, titanita e apatita, bem como por enriquecimento em feldspato potássico e biotita. A idade mínima de cristalização do corpo, definida pelo método $\mathrm{Pb}-\mathrm{Pb}$ em evaporação de zircão, de $1651 \pm 4 \mathrm{Ma}$, é interpretada como idade de colocação do protólito ígneo do Gnaisse Turvo, indicando um episódio magmático calcioalcalino de alto-K no Terreno Paraguá. As idades U-Pb SHRIMP em zircôes de $1641 \pm 4$ Ma para o Granito Refúgio (Santos et al. 2008) e $1673 \pm 21 \mathrm{Ma}$ para o Granito La Cruz (Matos et al. 2009), sugerem que o Gnaisse Turvo foi gerado neste evento ígneo de idade estateriana. Os dados geológicos, geoquímicos e geocronológicos $(\mathrm{Pb}-\mathrm{Pb})$ obtidos para o Gnaisse Turvo sugerem que a intrusão investigada foi gerada em um episódio magmático paleoproterozoico, provavelmente em um ambiente tectônico convergente, do tipo arco magmático continental, desenvolvido no proto-Terreno Paraguá, durante a Orogenia Lomas Manechis (1,7 a 1,6 Ga). Os dados estruturais, as relaçóes de campo e as informaçóes geocronológicas dos granitos Guaporeí e Passagem pertencentes ao Complexo Granitoide Pensamiento, indicam que o Gnaisse Turvo foi intensamente afetado pela Orogenia 
San Ignácio (1,4 a 1,3 Ga), responsável pela aglutinação do Terreno Paraguá ao Proto-cráton Amazônico.

\section{AGRADECIMENTOS}

\author{
Os autores agradecem ao Programa Nacional \\ de Cooperação Acadêmica (PROCAD; Processo \\ no 096/2007), à Fundação de Amparo à Pesquisa do Estado
}

do Mato Grosso (FAPEMAT; Processo no 004/2009), ao Instituto Nacional de Ciência e Tecnologia em Geociências da Amazônia (GEOCIAM) e à Coordenação de Aperfeiçoamento de Pessoal de Nível Superior (CAPES), respectivamente, pelo custeio das análises geocronológicas e químicas e pela concessão de bolsa de mestrado ao primeiro autor. Agradecemos aos revisores pelas sugestóes e correçóes que contribuíram com a melhoria substancial da qualidade do artigo.

\section{REFERÊNCIAS}

Barrett T.J. \& MacLean W.H. 1999. Volcanic sequences, lithogeochemistry and hydrothermal alteration in some bimodal volcanic-associated massive sulfide systems, in Volcanic-associated massive sulfide deposits: processes and examples (1999). Reviews in Economic Geology, 8:101-131.

Bettencourt J.S., Leite Jr W.B., Ruiz A.S., Matos R., Payolla B.L., Tosdal R.M. 2010. The Rondonian-San Ignacio Province in the SW Amazonian Craton: an overview. Journal of South American Earth Sciences, 29(1) Special issue:28-46.

Boger S.D., Raetz M., Giles D., Etchart E., Fanning C.M. 2005. U-Pb age data from the Sunsas region of Eastern Bolivia, evidence for the allochthonous origin of the Paragua Block. Precambrian Research, 139(3-4):121-146.

Cordani U.G., Tassinari C.C.G., Teixeira W., Basei M.A.S., Kawasita K. 1979. Evolução tectônica da Amazônia com base nos dados geocronológicos. In: Congresso Geológico Chileno, 2, Atas, p.137-48.

Cordani U.G. \& Teixeira W. 2007. Proterozoic accretionary belts of the Amazonian Craton. In: Hatcher, R.D. Jr., Carlson, M. P., Mcbride, J. H., Martinez Catalán J. R. (org). The 4D Framework of Continental Crust. Boulder, Colo: Geological Societyof America, 2007, p. 297-320. (Memoir. v. 200).

Cordani U.G., Teixeira W., Tassinari C.C.G., Coutinho J.M.V., Ruiz A.S. 2010. The Rio Apa Craton in Mato Grosso do Sul (Brazil) and northern Paraguay: Geochronological evolution, correlations and tectonic implications for Rodinia and Gondwana. American Journal of Sciences, 310(9):981-1023.

Figueiredo F.L.P., Ruiz A.S., Souza M.Z.A., Macambira M.J.B. 2009. Dados isotópicos $\mathrm{Pb}-\mathrm{Pb}$ em Zircão do Ortognaisse Turvo/Terreno Paraguá - SW do cráton Amazônico. Boletim de Resumos Expandidos, In: Simp. 45 Anos de Geocronologia no Brasil, p. 177-179.

Figueiredo F.L.P. 2010. Ortognaisse Turvo - registro de magmatismo paleoproterozoico no Terreno Paraguá - SW do Cráton Amazônico, Vila Bela da Santíssima Trindade, Mato Grosso. Dissertação de Mestrado, Instituto de Ciências Exatas e da Terra, Universidade Federal de Mato Grosso, Cuiabá, 60 p.

Fleuty M.J. 1964. The descriptions of folds. Proceedings of Geological Association of London, 75(4):461-492.

Gaudette H.E., Lafon J.M., Macambira M.J.B., Moura C.A.V., Scheller T. 1998. Comparison of single filament $\mathrm{Pb}$ evaporation/ionization zircon ages with conventional U-Pb results: examples from the Precambrian of Brazil. Journal of South American Earth Sciences, 11(4):351-363.

Geraldes, M.C. 2000. Geocronologia e geoquímica do plutonismo mesoproterozóico do SW do Estado de Mato Grosso (SW do Cráton Amazônico). Tese de Doutorado. Instituto de Geociências, Universidade de São Paulo, São Paulo, 193 p.
Harris N.B.W., Pearce J.A., Tindle A.G. 1986. Geochemical characteristics of collision zone magmatism. Geological Society, London, Special Publication, 19:67-81.

Irvine T.N. \& Baragar W.R.A. 1971. A guide to the chemical classification of the common volcanic rocks. Canadian Journal of Earth Sciences, 8(5):523-548.

Jesus G.C., Sousa M.Z.A., Ruiz A.S., Matos J.B. 2010. Petrologia e geocronologia (U-Pb/ Sm-Nd) do Granito Passagem, Complexo Granitóide Pensamiento, SW do Cráton Amazônico (MT). Revista Brasileira de Geociências, 40(3):392-408.

Kober B. 1986. Whole grain evaporation for $207 \mathrm{~Pb} / 206 \mathrm{~Pb}$ age investigations on single zircons using a double filament source. Contributions to Mineralogy and Petrology, 93:482-490.

Kober B. 1987. Single-zircon evaporation combined with $\mathrm{Pb}^{+}$emitter bedding for ${ }^{207} \mathrm{~Pb} /{ }^{206} \mathrm{~Pb}$-age investigations using thermal ion mass spectrometry, and implications for zirconology. Contributions to Mineralogy and Petrology, 96:63-71.

La Roche H. 1980. Granites chemistry through multicationic diagrams. Sciences de la Terre, Série Informatique Géologique, 13:65-88.

Le Bas M.J., Le Maitre R.W., Streckeisen A., Zanettin B. 1986. A chemical classification of volcanic rocks based on the total alkalisilica diagram. Journal of Petrology, 27(3):745-750.

Le Maitre R.W. 1989. A Classification of Igneous Rocks and Glossary of Terms: Recommendations of the International Union of Geological Sciences Subcommission on the Systematics of igneous rocks. Oxford, Blackwell, 193 p.

Litherland M., Annells R.N., Appleton J.D., Berrangé, J.P., Bloomfield, K., Burton, C.C.J., et al. (eds.) 1986. The Geology and Mineral Resources of the Bolivian Precambrian Shield. British Geological Survey. London, Her Majesty's Stationery Office, 140 p.

Maniar P.D. \& Piccoli P.M. 1989. Tectonic discrimination of granitoids. Geological Society of America, 101(5):635-643.

Matos J.B. \& Ruiz A.S. 1991. Contribuição à geologia da Folha Santa Rita - Mato Grosso. In: III Simp. Geol. Centro-Oeste, Anais, p. $122-130$.

Matos R., Teixeira W., Geraldes M.C., BettencourtJ.S. 2009. Geochemistry and Nd-Sr Isotopic Signatures of the Pensamiento Granitoid Complex, Rondonian-San Ignacio Province, East Precambrian Shield of Bolívia: Petrogenetic Constraints for a Mesoproterozoic Magmatic Arc Setting. Geologia USP, Série Científica, 9(2):89-117.

Nakamura K. 1977. Volcanoes as possible indicator of tectonic stress orientation: principle and proposal. Journal of Volcanology and Geothermal Research, 2(1):1-16. 
Nalon P.A. 2010. O Batólito Guaporeí - uma intrusão mesoproterozóica do Complexo Granitóide Pensamiento em Mato Grosso, SW do Cráton Amazônico. Dissertação de Mestrado, Instituto de Ciências Exatas e da Terra, Universidade Federal de Mato Grosso, Cuiabá, 54 p.

Nalon P.A., Sousa M.Z.A., Ruiz A.S., Macambira M.J.B. (2013). Batólito Guaporeí: uma extensão do Complexo Granitoide Pensamiento em Mato Grosso, SW do Cráton Amazônico. Brazilian Journal of Geology. 43(1):85-100

Peacock M.A. 1931. Classification of igneous rock series. Journal of Geology, 39(1):54-67.

Pearce J.A., Harris N.B.W., Tindle A.G. 1984. Trace element discrimination diagrams for the tectonic interpretation of granitic rocks. Journal of Petrology, 25(4):956-983.

Peccerillo A. \& Taylor S.R. 1976. Geochemistry of Eocene calcalkaline volcanic rocks from the Kastamonu area, northern Turkey. Contributions to Mineralogy and Petrology, 58:63-81.

Ruiz A.S. 2005. Evolução Geológica do Sudoeste do Cráton Amazônico Região Limítrofe Brasil-Bolívia-Mato Grosso. Tese de Doutorado, Instituto de Geociências e Ciências Exatas, Universidade Estadual Paulista, Rio Claro, 250 p.

Ruiz A.S., Sousa M.Z.A., Matos J.B., Lima G.A. 2007. Geologia do Domínio Tectônico Paraguá, SW do Cráton Amazônico - Fronteira Brasil-Bolívia. In: X Simp. Geol. Centro-Oeste, Anais.

Ruiz, A.S. 2009. Compartimentação Tectônica (Pré-Sunsás) do SW do Cráton Amazônico: ênfase em Mato Grosso - Brasil. In: Congresso Geológico Boliviano, 18, Actas, p. 159-163.

Santos J.O.S., Hartmann L.A., Gaudette H.E., Groves D.I., Mcnaughton N.J., Fletcher I.R.A. 2000. New understanding of the provinces of the Amazon Craton based on integration of field mapping and $\mathrm{U}-\mathrm{Pb}$ and $\mathrm{Sm}-\mathrm{Nd}$ geochronology. Gondwana Research, 3(4):453-488.
Santos J.O.S., Rizzotto G.J., Potter P.E., McNaughton N.J., Matos R.S., Hartmann L.A., et al. 2008. Age and autochthonous evolution of the Sunsás Orogen in West Amazon Craton based on mapping and U-Pb geochronology. Precambrian Research, 165(3-4):120-152.

Scheepers R. 1995. Geology, geochemistry and petrogenesis of Late Precambrian S-, I- and A- type granitoids in the Saldania belt, Western Cape Province, South Africa. Journal of African Earth Sciences, 21(1):35-58.

Steiger R.H. \& Jäger E. 1977. Subcommission on geochronology: convention of the use of decay constants in geo- and comoschronology. Earth and Planetary Science Letters, 36:359-362.

Tassinari C.C.G. 1996. O Mapa Geocronológico do Cráton Amazônico no Brasil: revisão dos dados isotópicos. Tese de Livre-docência, Instituto de Geociências, Universidade de São Paulo, São Paulo, 139 p.

Tassinari C.C.G., Bettencourt J.S., Geraldes M.C., Macambira M.J.B., Lafon J.M. 2000. The Amazonian Craton. In: Cordani, U.G., Milani, E.J., Thomaz Filho, A., Campos, D.A. (eds.). Tectonic evolution of South America - 31 $1^{\text {st }}$ IGC. Rio de Janeiro, CPRM, p. 41-95.

Tassinari C.C.G. \& Macambira M.J.B. 1999. Geochronological provinces of the Amazonian Craton. Episodes, 22:174-182

Tassinari C.G.C. \& Macambira M.J.B. 2004. A evolução tectônica do Cráton Amazônico. In: Neto-Mantesso V., Bartorelli A, Carneiro C. D. R., Brito-Neves B.B. (eds.). Geologia do continente sul- americano: evolução da obra de Fernando Flávio Marques de Almeida. São Paulo, Beca, p. 471-486.

Vernon, R.H. 1991. Interpretation of microstructures of microgranitoid enclaves. In: Didier, J. \& Barbarin, B. (eds.). Enclaves and Granite Petrology. Elsevier, Amsterdam, p. 277-291.

Winchester J.A. \& Floyd P.A. 1977. Geochemical discrimination of different magma series and their differentiation products using immobile elements. Chemical Geology, 20:325-343.

Arquivo digital disponível on-line no site www.sbgeo.org.br 